\title{
Regiony hydrogeotermalne na Niżu Polskim
}

\author{
Jerzy Nawrocki ${ }^{1}$, Mariusz Socha ${ }^{1}$
}

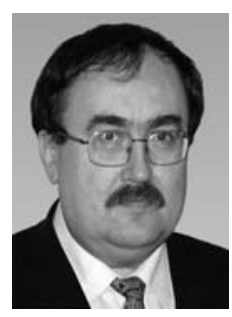

J. Nawrocki

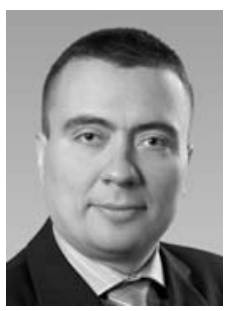

M. Socha

Hydrogeothermal regions of the Polish Lowlands. Prz. Geol., 69: 578-593; doi: 10.7306/2021.32

A b s tr a c t. The paper provides a proprsal to divide the three main Mesozoic hydrogeothermal reservoirs of the Polish Lowlands into regions. The division is based primarily on reservoir efficacy in terms of using thermal waters for heating and recreation purposes. The presented validation of individual regions and sub-regions shows that only some parts of them have a medium or high heating potential. The heating and recreation potentials are limited in many places by the high mineralization of thermal waters.

Regionalizacja zbiorników hydrogeotermalnych Niżu Polskiego $^{2}$ nie jest zadaniem łatwym nie tylko dlatego, że musi uwzględniać zmienność poziomą i pionową wielu istotnych dla potencjału geotermalnego parametrów, ale również, dlatego że zmienność ta musi być konfrontowana ze stopniem użyteczności wód termalnych do różnych celów, w ramach których stworzono odrębne wymogi. Co więcej na stopień użyteczności wód termalnych mają również wpływ zmieniajace się $\mathrm{w}$ czasie technologie związane $\mathrm{z}$ pozyskiwaniem i wykorzystywaniem tych wód. Mimo świadomości wielu ograniczeń, podjęliśmy się jednak próby podziału zbiorników hydrogeotermalnych Niżu Polskiego na regiony, a następnie ich wartościowania. Głównym celem tej użytkowej regionalizacji wybranych zbiorników hydrogeotermalnych mezozoiku Niżu Polskiego było uproszczenie dostępnej informacji specjalistycznej (Górecki, 2006) do formy łatwiejszej do wykorzystania przez niespecjalistów, którzy mogą mieć wpływ na decyzje związane z uruchamianiem, lub nie, w danym miejscu inwestycji geotermalnej. Wyniki takiej wstępnej oceny mogą się także okazać przydatne do podjęcia decyzji o przeprowadzeniu dalszych badań uszczegółowiających. Artykuł ten zawiera najistotniejsze elementy opracowania archiwalnego, które było poświęcone polu geotermalnemu i regionom geotermalnym na Niżu Polskim (Nawrocki, 2021).

O możliwości wykorzystania wód termalnych ze zbiorników mezozoicznych na Niżu Polskim wypowiadano się na łamach czasopism naukowych już wiele lat temu (np. Ney, Sokołowski, 1987). Na obszarze naszego kraju przeprowadzono także ogólny podział regionalny na prowincje i baseny geotermalne (Sokołowski, 1995). W zakresie syntetycznych opracowań kartograficznych, poza Atlasem zasobów geotermalnych na Niżu Polskim (Górecki, 2006), będącym dla tej publikacji podstawowym źródłem danych, wydano też np. Mape zagospodarowania wód podziemnych zaliczanych do kopalin w Polsce (Felter i in., 2017).

\section{METODYKA}

Wydzielenie regionów geotermalnych, przeprowadzone tutaj $\mathrm{w}$ ujęciu funkcjonalnym, oparto na ewaluacji danych z mezozoicznych zbiorników hydrogeotermalnych Niżu Polskiego, zestawionych przez Góreckiego (2006). Jedyną ich modyfikacją było obniżenie o $30 \%$ prognozowanej wydajności z otworu, gdyż w cytowanym opracowaniu przyjęto zbyt dużą, przy dzisiejszych instalacjach niepraktykowaną, średnicę otworu eksploatacyjnego. W pracy nie uwzględniono nielicznych aktualniejszych danych z pojedynczych otworów, jak również nowszych opracowań o charakterze syntetycznym (np. Hajto, 2008; Bielec i in., 2014; Bujakowski, Barbacki, 2016; Sowiżdżał i in., 2020), które jednak nie doprowadziły jak dotychczas do aktualizacji wspomnianego wyżej opracowania integrującego dane w skali całego Niżu Polskiego. Stąd dla jednorodności metodycznej autorzy oparli się wyłącznie na opracowaniu Góreckiego (2006). Przeprowadzone w drugiej części tej publikacji wartościowanie regionów geotermalnych nie uwzględnia czynnika demograficznego i innych warunków panujących na powierzchni danego obszaru. Opisy uwarunkowań tektonicznych charakteryzujących piętro mezozoiczne w danym regionie wykonano głównie na podstawie informacji zawartych w opracowaniu Dadleza (1998). Część regionów, w których zaobserwowano istotne zróżnicowanie wielkości co najmniej jednego z dwóch kluczowych parametrów - temperatury lub/i mineralizacji - podzielono na subregiony. Zastosowane tutaj nazewnictwo jednostek regionalnych nawiązuje do nazw miejscowości (przy ich dużej rozciągłości, zwykle położonych w skrajnie odległych miejscach danego regionu), rzek lub krain geograficznych Polski. Symbolikę literową i cyfrową, występującą obok nazw regionów i subregionów, wprowadzono jako pomocną przy skrótowych zestawieniach tabelarycznych potencjału geotermalnego analizowanych basenów. W przyszłości zapewne należałoby ją uzupełnić skrótami nazw jednostek geologicznych zawierających dany basen geotermalny oraz symbolem związanym z formą wykorzystania wód termalnych.

W przedstawionej tutaj regionalizacji podział basenów geotermalnych nawiązuje do ich wykorzystania w ciepłownictwie obejmującym odrębnie temperatury wód w stropie danego zbiornika powyżej $60^{\circ} \mathrm{C}$ (bezpośrednie wykorzy-

\footnotetext{
${ }^{1}$ Państwowy Instytut Geologiczny - Państwowy Instytut Badawczy, ul. Rakowiecka 4, 00-975 Warszawa; jerzy.nawrocki@pgi.gov.pl; mariusz.socha@pgi.gov.pl

${ }^{2}$ Niż Polski jest tutaj w ujęciu szerszym, stosowanym np. w naukach biologicznych. Są to tereny Polski poza pasmami Karpat i Sudetów.
} 
stanie) i w przedziale $40-60^{\circ} \mathrm{C}$ (ciepłownictwo wspomagane pompami absorpcyjnymi). Nie analizowano obszarów $\mathrm{z}$ wodami o temperaturze niższej od $40^{\circ} \mathrm{C}$, które ewentualnie mogą być wykorzystane w ciepłownictwie wspomaganym użyciem pomp sprężarkowych (Pająk, Bujakowski, 2018). Należy także podkreślić, że ciepłownictwo związane z wykorzystaniem wód o temperaturze wyższej nawet od $60^{\circ} \mathrm{C}$ bywa również wspomagane pompami absorpcyjnymi lub innymi źródłami ciepła. Regionalizację przeprowadzono także w odniesieniu do wód przydatnych do celów rekreacyjnych. Nie zajmowano się wykorzystaniem wód w balneologii, głównie ze względy na wciąż jeszcze szczupły zbiór wiarygodnych danych otworowych dotyczących tego aspektu. Z regionalizacji wyłączono obszary analizowanych zbiorników, które nie spełniały podstawowych, przyjętych tutaj kryteriów w zakresie dwóch zasadniczych parametrów - temperatury i mineralizacji. W miejscach, gdzie wartości tych dwóch parametrów były wystarczające, nie stwierdzono też zbyt niskiej prognozowanej wydajności z otworu, która eliminowałoby go zupełnie $\mathrm{z}$ analizowanych kierunków wykorzystania wód. Jak wspomniano, temperatura minimalna przyjęta dla wykorzystania ciepłowniczego wód geotermalnych to $40^{\circ} \mathrm{C}$ w stropie danego zbiornika, a maksymalna mineralizacja wód termalnych przeznaczonych do tego celu to $100 \mathrm{~g} / \mathrm{dm}^{3}$. Taką wartość progową mineralizacji przyjęto mimo świadomości, że niektóre instalacje geotermalne na Niżu Polskim wykorzystują wody o wyraźnie wyższej mineralizacji. Przy dosyć skomplikowanej architekturze depozycyjnej skał, zwłaszcza dolnego triasu i dolnej jury, gdzie często skały o dobrych własnościach zbiornikowych są zastępowane obocznie skałami o znacznie gorszych parametrach, dalsze podnoszenie ryzyka braku miejsca w górotworze na zatłaczane zużyte wody nie wydaje się jednak w dłuższej perspektywie czasu być uzasadnionym Prowadzi to prędzej czy później do konieczności wykonywania kolejnych otworów chłonnych. Ryzyko to wiąże się z faktem, że przy obniżeniu temperatury solanki, a także zmianie innych jej parametrów fizyczno-chemicznych, wytrącenie się z niej nowych minerałów prowadzi w otworze zatłaczającym do kolmatacji szczelin i porów (zob. np. Biernat i in., 2011). Można oczywiście zatłaczać w inne niż eksploatowane horyzonty skalne, o dobrych własnościach zbiornikowych. Jednak taki proces byłby już składowaniem substancji w innym środowisku geologicznym.

Minimalną temperaturę wód termalnych, przewidzianych do wykorzystania rekreacyjnego przyjęto tutaj jako wyższą niż $20^{\circ} \mathrm{C}$. Ich maksymalna, przyjęta tutaj mineralizacja to $35 \mathrm{~g} / \mathrm{dm}^{3}$. Wody o wyższej mineralizacji wymagałyby rozcieńczenia, co bardzo znacząco wpływałoby na ekonomikę przedsięwzięcia geotermalnego (zob. Rajchel, 2006). Nie wprowadzono ograniczenia dotyczącego górnej granicy temperatury wód wykorzystywanych w rekreacji, zakładając, że wody o wysokiej temperaturze będą schładzane, służąc również ciepłownictwu.

Niedokładności wyznaczania granic regionów i subregionów nawiązują w sposób oczywisty do błędów analitycznych interpolacji danych źródłowych, wynikających głównie z ograniczonej ilości punktów pomiarowych. Granice te są bardzo przybliżone, w szczególności, gdy przyjęta wartość graniczna temperatury lub mineralizacji wód termalnych jest wynikiem interpolacji między odległymi punktami, różniącymi się znacznie wartościami tych parametrów. W przypadku bardzo wąskich regionów lub subregionów o dużej rozciagłości przestrzennej, przy niedostatku danych użytych do interpolacji, ich ciagłość może okazać się nieprawdziwa, gdyż mogą zawierać enklawy nie spełniające warunków progowych. Dlatego w tych miejscach przedstawiona tutaj regionalizacja powinna być traktowana jako zupełnie wstępna. Z pewnością napływ nowych danych zweryfikuje przybliżony zarys granic regionów i subregionów, zwłaszcza na tych niedostatecznie udokumentowanych obszarach.

Wartościowanie regionów i subregionów geotermalnych basenów mezozoicznych Niżu Polskiego przeprowadzono na podstawie arbitralnie wyznaczonych wag podstawowych parametrów i finalnie - kategorie ich przydatności. Za najważniejsze parametry uznano temperaturę wód, stopień ich mineralizacji i w drugiej kolejności prognozowaną wydajność z otworu. Dwa ostatnie parametry, którym przyznano mniejszą wagę, to wartość strumienia cieplnego (Szewczyk, Gientka, 2009) i głębokość spąu poziomów wodonośnych. Należy tutaj jednak podkreślić, że w konkretnych warunkach inwestycyjnych, np. przy ograniczonych środkach na wykonanie otworu geotermalnego, ten ostatni parametr będzie równie istotny, jak parametry wyżej punktowane, niezbędne dla powodzenia przedsięwzięcia. Podobnie, przy planowanej intensywnej i długotrwałej eksploatacji wód termalnych na potrzeby ciepłownictwa wyższe wartości strumienia cieplnego i związana $\mathrm{z}$ nimi szybsza odnawialność cieplna eksploatowanych struktur skalnych stają się elementami niezwykle istotnymi. Strumień cieplny określano w tym opracowaniu dla uproszczenia jako: bardzo niski $\left(<55 \mathrm{~mW} / \mathrm{m}^{2}\right)$, niski $\left(55-70 \mathrm{~mW} / \mathrm{m}^{2}\right)$, średni (70-90 mW/m²) i wysoki $\left(>90 \mathrm{~mW} / \mathrm{m}^{2}\right)$. Stopień mineralizacji wód termalnych przyjęto jako niski dla wartości $<5 \mathrm{~g} / \mathrm{dm}^{3}$, średni -5 a $35 \mathrm{~g} / \mathrm{dm}^{3}$, natomiast wysoki i bardzo wysoki, gdy wynosi on odpowiednio od 36 do $100 \mathrm{~g} / \mathrm{dm}^{3}$ oraz powyżej $100 \mathrm{~g} / \mathrm{dm}^{3}$. Różnica w wagach punktacji regionów i subregionów z potencjałem ciepłowniczym z temperaturami wyższymi od $60^{\circ} \mathrm{C}$ i zawartymi pomiędzy 40 a $60^{\circ} \mathrm{C}$ dotyczy tylko innych głębokości granicznych spagu zalegania poziomów wodonośnych. W przypadku wartościowania regionów i subregionów geotermalnych $\mathrm{z}$ potencjałem w zakresie rekreacji przyjęta punktacja dotyczy oczywiście innych, charakterystycznych dla tego kierunku wykorzystania wartości mineralizacji, temperatur i wydajności. Przyjęte punkty procentowe dla poszczególnych regionów i subregionów często nie są tożsame $\mathrm{z}$ wartościami progowymi podanymi w objaśnieniach tabel, co wynika z niejednorodności niektórych parametrów na ich obszarze. Na przykład punktacja procentowa dla regionu, który w $2 / 3$ będzie leżał w strefie wysokiego strumienia cieplnego, a w 1/3 w strefie jego średnich wartości, wynosi w przedstawionym zestawieniu $8 \%$. Przydatność regionów i subregionów dla wykorzystania wód termalnych określono w skali czterostopniowej, w której przydatność wysoka (A) wiąże się z sumą punktów procentowych wyższą od 70, umiarkowana (B) - z punktami zawartymi w przedziale 50-70, niska (C) - z sumą punktów w przedziale 25-49. Nie wyróżniono tutaj regionów i subregionów nieprzydatnych z sumą punktów niższą od 25, co wiąże się z wyłączeniem już na wstępie tych obszarów basenów geotermalnych, które nie spełniały parametrów progowych. 


\section{BASEN HYDROGEOTERMALNY DOLNEJ KREDY}

\section{Regiony z potencjałem ciepłowniczym}

Region brodnicko-mszczonowski (A). Rozciąga się od doliny dolnej Drwęcy przez Płock do okolic Mszczonowa (ryc. 1), zajmując centralną część synklinorium koszalińsko-zamojskiego. Zaangażowanie tektoniczne skał permo-mezozoiku jest tutaj umiarkowane. Obecność uskoków o głębszych założeniach może skutkować lokalnym wzrostem mineralizacji wód termalnych i w konsekwencji obniżeniem ich walorów użytkowych.

W regionie brodnicko-mszczonowski występują wody termalne o temperaturze od ok. 40 do ok. $55^{\circ} \mathrm{C}$ i zasoleniu mniejszym od $5 \mathrm{~g} / \mathrm{dm}^{3}$, poza jego północno-zachodnim krańcem, gdzie mineralizacja jest wyższa, ale nie przekraczająca $35 \mathrm{~g} / \mathrm{dm}^{3}$. Prognozowana wydajność wynosi tutaj od kilkudziesięciu do ponad $100 \mathrm{~m}^{3} / \mathrm{h}$. Wody termalne na zachodnim krańcu regionu charakteryzują się średnią wartością strumienia cieplnego (nieco powyżej $70 \mathrm{~mW} / \mathrm{m}^{2}$ ), zaś na pozostałej części jest strumień niski, w rejonie Brodnicy nawet bardzo niski, tj. poniżej $55 \mathrm{~mW} / \mathrm{m}^{2}$. Poza doliną dolnej Bzury i obszarem występowania poduszek solnych, gdzie skały dolnej kredy miejscami uległy zafałdowaniu i zuskokowaniu, region charakteryzuje generalnie połogie, niezaburzone ułożenie warstw dolnej kredy. Warstwy wodonośne w basenie geotermalnym dolnej kredy regionu brodnicko-mszczonowskiego stanowią głównie piaskowce baremu, aptu i albu ujęte w ogniwa pagórczańskie, goplańskie i kruszwickie. Spag utworów dolnej kredy znajduje się na głębokościach ok. 1100-1700 m. Sumaryczna miąższość warstw wodonośnych to 50-200 m.

Region żnińsko-pabianicki (B). Jest to region występowania w utworach dolnej kredy wód termalnych o temperaturze od ok. 40 do ponad $60^{\circ} \mathrm{C}$. Ich mineralizacja jest średnia, a w centralnej i północnej części regionu wysoka,

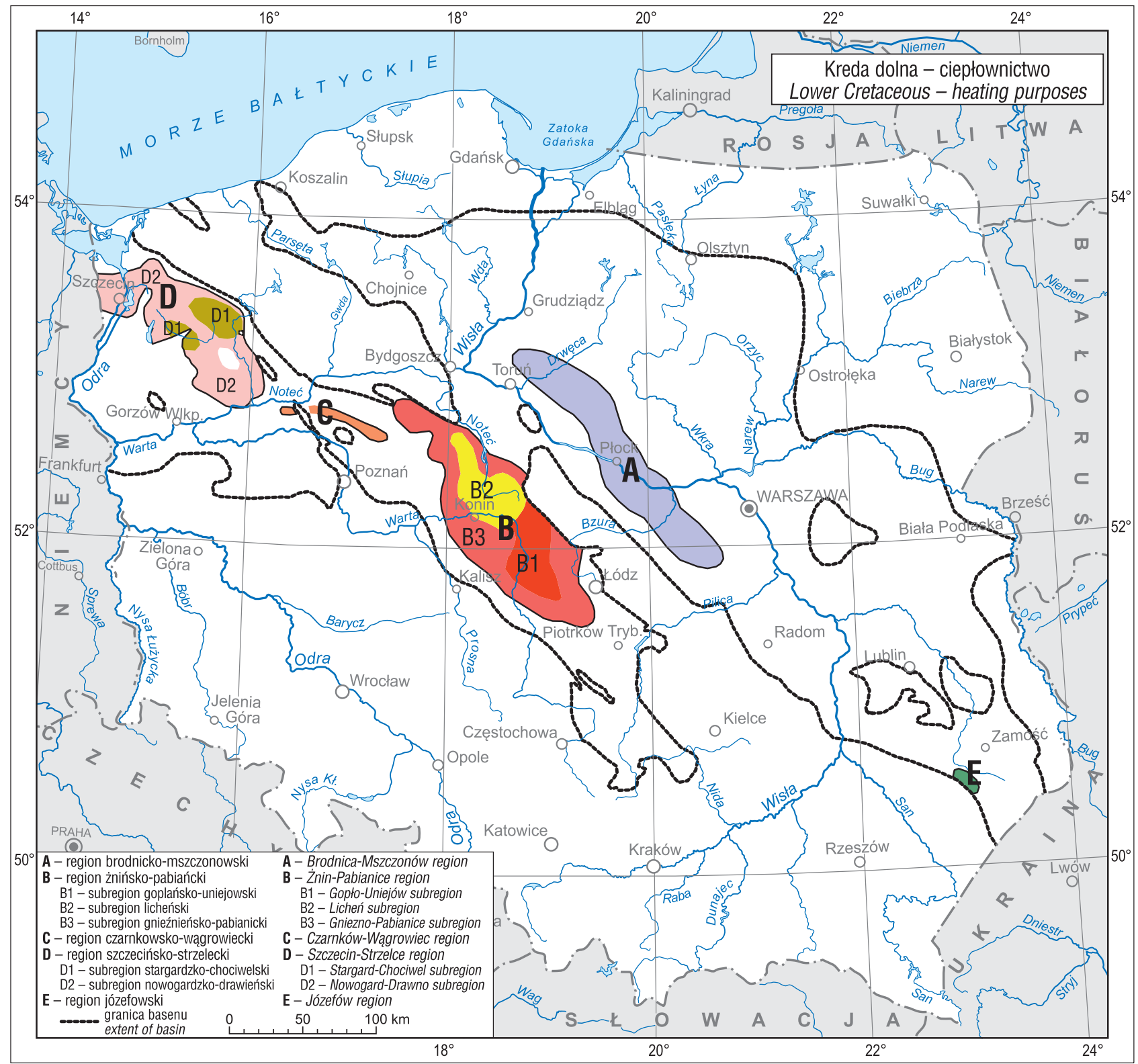

Ryc. 1. Regiony występowania wód geotermalnych w zbiorniku kredy dolnej na Niżu Polskim, potencjalnie użytecznych do celów ciepłownictwa

Fig. 1. Regions of geothermal water occurrence in the Lower Cretaceous reservoir in the Polish Lowlands, potentially useful for heating purposes 
miejscami przekraczająca $100 \mathrm{~g} / \mathrm{dm}^{3}$. Względnie wysokie prognozowane wydajności powinny zawierać się w przedziale od kilkudziesięciu do ponad $100 \mathrm{~m}^{3} / \mathrm{h}$. Wartość strumienia cieplnego waha się między 70 a $90 \mathrm{~mW} / \mathrm{m}^{2}$. Skały mezozoiczne uległy tutaj $\mathrm{w}$ wielu miejscach procesom związanym z tektoniką solną. Tworzą one szereg wydłużonych, głównie w kierunku NW-SE, form fałdowych. Spag utworów dolnej kredy znajduje się tutaj w zależności od lokalizacji na głębokości od kilometra do $2500 \mathrm{~m}$. Tylko w dwóch izolowanych miejscach głębokość ta jest nieznacznie większa. Łączna miąższość ulokowanych w nich poziomów wodonośnych wynosi średnio ok. $100 \mathrm{~m}$, chociaż wzrasta w kilku miejscach do $250 \mathrm{~m}$, a w obrębie wschodniego krańca regionu spada do kilkudziesięciu metrów. Skały tego wieku to w omawianym regionie piaskowce z wkładkami mułowców formacji włocławskiej (ogniwa: pagórzańskie, goplańskie i kruszwickie) i mogileńskiej (ogniwa: gniewkowskie, żychlińskie i wierzchosławickie). Pierwsza formacja ujmuje osady baremu-albu, natomiast druga - walanżynu i hoterywu.

Subregion goplańsko-uniejowski (B1). Subregion ten charakteryzują temperatury wód basenu hydrogeotermalnego dolnej kredy przekraczające $60^{\circ} \mathrm{C}$. Obszar ten, poza temperaturami wód geotermalnych wyższymi od $60^{\circ} \mathrm{C}$, charakteryzuje się niską (południowa część) i średnią mineralizacja wód geotermalnych, która nie przekracza $35 \mathrm{~g} / \mathrm{dm}^{3}$. Należy jednak podkreślić, że ze względu na lokalne zaangażowanie tektoniczne skał mezozoiku, zwłaszcza związane z tektoniką solną, istnieje ryzyko, że w niektórych jego miejscach mogą występować wody o wyższej mineralizacji. Głębokość spągu utworów kredy wynosi tutaj od 2 do $2,5 \mathrm{~km}$.

Subregion licheński (B2). Subregion ten różni się od poprzedniego wyłącznie stopniem zasolenia wód geotermalnych, które będzie tam wyższe od $35 \mathrm{~g} / 1$, a miejscami może nawet przekraczać $100 \mathrm{~g} / 1$.

Subregion gnieźnieńsko-pabianicki (B3). Temperatury wód termalnych basenu dolnokredowego wynoszą tutaj od 40 do $60^{\circ} \mathrm{C}$. Ich mineralizacja jest zróżnicowana - niskie wartości $\left(<5 \mathrm{~g} / \mathrm{dm}^{3}\right)$ występują w południowej części subregionu, średnie $\left(5-35 \mathrm{~g} / \mathrm{dm}^{3}\right)$ w jego centrum, natomiast wysokich, przekraczające $35 \mathrm{~g} / \mathrm{dm}^{3}$ można się spodziewać na północy, w pobliżu Gniezna. Spąg utworów dolnej kredy znajduje się tutaj zasadniczo na głębokości ok. $1 \mathrm{~km}$. Cechą charakterystyczną środkowej i południowej części tego obszaru jest umiarkowana mineralizacja wód termalnych, która na jego południowym krańcu nie powinna przekraczać $5 \mathrm{~g} / \mathrm{dm}^{3}$, zaś w pozostałej części waha się w przedziale $5-35 \mathrm{~g} / \mathrm{dm}^{3}$. Fragment północny subregionu, rozciągający się od Konina do Żnina, a potem otaczający od wschodu subregion goplańsko-uniejowski aż po okolice Piotrkowa Kujawskiego, charakteryzuje się mineralizacją wód geotermalnych basenu dolnokredowego, która przekracza $35 \mathrm{~g} / \mathrm{dm}^{3}$. Temperatura wód termalnych wynosząca ok. $40-60^{\circ} \mathrm{C}$, w okolicy Żnina możne lokalnie przekraczać $60^{\circ} \mathrm{C}$.

Region czarnkowsko-wągrowiecki (C). Ten wąski pas basenu hydrogeotermalnego kredy dolnej zawiera wody termalne o temperaturze $40-50^{\circ} \mathrm{C}$. Prognozowana wydajność to od kilkudziesięciu do ok. $100 \mathrm{~m}^{3} / \mathrm{h}$. Strop utworów dolnej kredy znajduje się na głębokości od 1 do $1,5 \mathrm{~km}$. Region czarnkowsko-wagrowiecki znajduje się, podobnie jak żnińsko-pabianicki, na obszarze o umiarkowanej wartości strumienia cieplnego. Jego zachodnia i centralna część to miej- sce intensywnej tektoniki solnej. Mineralizacja wód termalnych jest tam wysoka, na ogół wynosi ponad $35 \mathrm{~g} / \mathrm{dm}^{3}$. Pozostała część regionu charakteryzuje się niską i umiarkowaną mineralizacją wód termalnych zbiornika dolnej kredy. Mineralizacja ta w jego najbardziej wschodniej części nie przekracza $5 \mathrm{~g} / \mathrm{dm}^{3}$. Łączna miąższość poziomów wodonośnych wynosi od kilkudziesięciu do ok. $100 \mathrm{~m}$. Skały wodonośne to piaskowce albu.

Region szczecińsko-strzelecki (D). Wody termalne zbiornika dolnokredowego tego regionu charakteryzują temperatury zawarte przeważnie $\mathrm{w}$ przedziale $40-60^{\circ} \mathrm{C}$. Tylko w jego centralnej części, ujętej poniżej jako subregion stargardzko-chociwelski, temperatury te przekraczaja $60^{\circ} \mathrm{C}$. Mineralizacja tych wód jest wysoka, a miejscami nawet bardzo wysoka - przekracza wartość $100 \mathrm{~g} / \mathrm{dm}^{3}$. Potencjalne wydajności w północnej części wyróżnionego regionu to kilkadziesiąt $\mathrm{m}^{3} / \mathrm{h}$. W jego południowej części wydajności spadają do kilku lub kilkunastu $\mathrm{m}^{3} / \mathrm{h}$. Cały region to obszar związany ze zjawiskami tektoniki solnej, z licznymi poduszkami solnymi i diapirami penetrującymi skały triasu lub jury. Południowo-zachodnie krańce regionu szczecińsko-strzeleckiego charakteryzuje wysoki strumień cieplny $\left(>90 \mathrm{~mW} / \mathrm{m}^{2}\right)$, natomiast pozostała jego część to obszar o średnich wartościach strumienia cieplnego (70$90 \mathrm{~mW} / \mathrm{m}^{2}$ ). Skały dolnej kredy, których spag występuje na głębokości od ok. $900 \mathrm{~m}$ do ok. $1800 \mathrm{~m}$, to piaskowce albu, reprezentujące fragment formacji mogileńskiej. Łączna miąższość poziomów wodonośnych nie przekracza $25 \mathrm{~m}$.

Subregion stargardzko-chociwelski (D1). Wyróżniony niewielki fragment regionu szczecińsko-strzeleckiego cechuje temperatura wód geotermalnych zbiornika kredy dolnej przekraczająca $60^{\circ} \mathrm{C}$. Niestety mineralizacja tych wód jest również wysoka, gdyż może przekraczać $100 \mathrm{~g} / \mathrm{dm}^{3}$.

Subregion nowogardzko-drawieński (D2). To pozostała, najrozleglejsza część regionu szczecińsko-strzeleckiego, gdzie temperatura wód geotermalnych wynosi $40-60^{\circ} \mathrm{C}$, ich mineralizacja jest niższa od $100 \mathrm{~g} / \mathrm{dm}^{3}$, a w brzeżnych fragmentach subregionu spada do ok. $50 \mathrm{~g} / \mathrm{dm}^{3}$.

Region józefowski (E). Ten bardzo niewielki, znajdujący się w południowo-wschodniej Polsce obszar charakteryzuje się wodami termalnymi o temperaturach 40 $50^{\circ} \mathrm{C}$, mineralizacji $35-100 \mathrm{~g} / \mathrm{l}$ i wydajności od kilku do kilkunastu $\mathrm{m}^{3} / \mathrm{h}$. Spag kredy dolnej znajduje się tam na głębokości ok. $1100 \mathrm{~m}$. Miąższość warstw wodonośnych osiagga tylko kilkanaście metrów. Warstwy te to piaski i piaskowce glaukonitowe albu. Strumień cieplny w regionie józefowskim jest niski (ok. $60 \mathrm{~mW} / \mathrm{m}^{2}$ ).

\section{Regiony $\mathrm{z}$ potencjałem w zakresie rekreacji}

Region nadwiślański (A). Region ten obejmuje zasadniczo część zlewni dolnej i środkowej Wisły, rozciągając się od Pomorza i Warmii przez Kujawy do południowych krańców Mazowsza (ryc. 2), obejmuje znaczną część monokliny mazursko-podlaskiej, a także środkowy segment synklinorium koszalińsko-zamojskiego. Mineralizacja wód termalnych $\mathrm{w}$ regionie nadwiślańskim miejscami spada poniżej $5 \mathrm{~g} / \mathrm{dm}^{3}$. Temperatura tych wód wynosi od 20 do ok. $50^{\circ} \mathrm{C}$. Najwyższe jej wartości zanotowano w pasie rozciągającym się od Mszczonowa przez Płock do doliny dolnej Drwęcy, najniższe występują w pasie brzeżnym regionu od strony północnej i wschodniej. Wyróżniony teren charakteryzuje niski strumień cieplny i niewielki stopień zaangażowania tektonicznego formacji mezozoicz- 


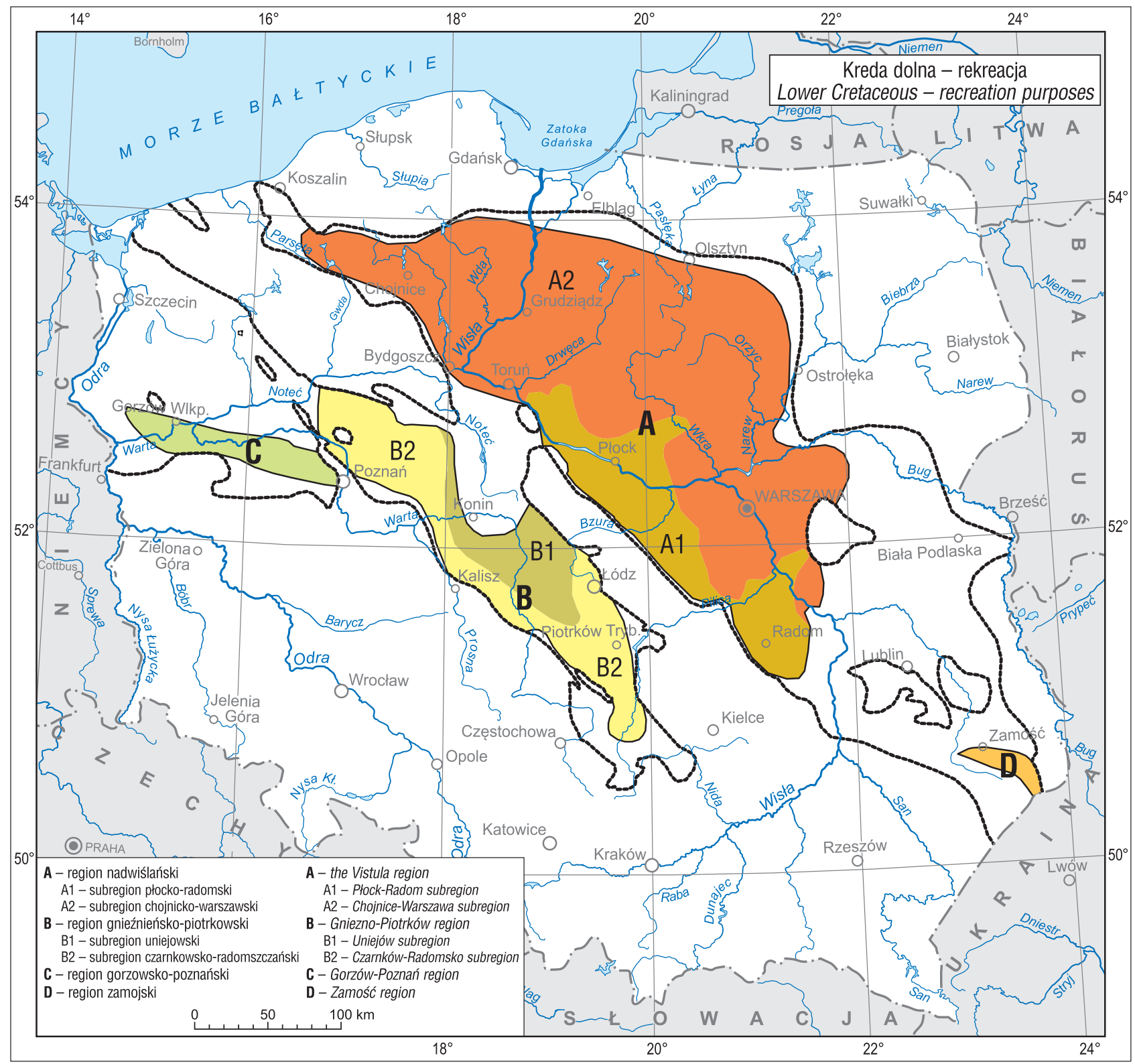

Ryc. 2. Regiony występowania wód geotermalnych w zbiorniku kredy dolnej na Niżu Polskim, potencjalnie użytecznych do celów rekreacji

Fig. 2. Regions of geothermal water occurrence in the Lower Cretaceous reservoir in the Polish Lowlands, potentially useful for recreation purposes

nych, poza wspomnianym pasem w jego południowo-zachodniej części. Spodziewane wydajności studni powinny wynosić tutaj od kilkunastu na peryferiach regionu do nawet $100 \mathrm{~m}^{3} / \mathrm{h}$ w centralnej i zachodniej jego części. Miąższość warstwy wodonośnej wynosi od 20 do ponad $200 \mathrm{~m} \mathrm{w}$ rejonie Torunia, Płocka i Łowicza. Warstwę tę tworzą głównie piaski i piaskowce albu (ogniwo kruszwickie), w mniejszej części barremu (ogniwo pagórczańskie) i walanżynu (formacja bodzanowska).

Subregion płocko-radomski (A1). Subregion ten wyróżnia się wodami o bardzo niskiej, nie przekraczającej $5 \mathrm{~g} / \mathrm{dm}^{3}$ mineralizacji, a także przewidywaną dużą wydajnością ich ujęć. Temperatura wód w jego przeważającej części wynosi $40-50^{\circ} \mathrm{C}$. To wszystko sprawia, że subregion ten jest jednym z najlepszych na Niżu Polskim w zakresie możliwości zagospodarowania wód termalnych do celów rekreacyjnych. Przy doborze miejsc do wykonania instalacji należy jednak wykluczać miejsca o większym zaangażowaniu tektonicznym, gdzie może dochodzić do lokalnego wzrostu zasolenia wód. Spag warstw kredy dolnej w wyróżnionym subregionie, w zależności od miejsca, znajduje się na głębokości ok. 1200-1700 m.

Subregion chojnicko-warszawski (A2). Jest to rozległy obszar monokliny mazursko-podlaskiej i synklinorium koszalińsko-zamojskiego, gdzie mineralizacja wód termalnych przekracza $5 \mathrm{~g} / \mathrm{dm}^{3}$ i w centralnej części subregionu może dochodzić do $30 \mathrm{~g} / \mathrm{dm}^{3}$. W pasie brzeżnym od strony północnej i wschodniej subregionu występują wody, których temperatura tylko niewiele przekracza $20^{\circ} \mathrm{C}$, a prognozowana wydajność studni będzie wynosić od kilku do kilkunastu $\mathrm{m}^{3} / \mathrm{h}$. Spag warstw kredy dolnej w zależności od miejsca znajduje się tutaj na głębokości od ok. $800 \mathrm{~m}$ do ok. $1400 \mathrm{~m}$.

Region gnieźnieńsko-piotrkowski (B). Region ten charakteryzują średnie, a na jego zachodnim krańcu wysokie wartości strumienia cieplnego. Znaczna jego część jest położona na obszarze, gdzie $\mathrm{z}$ różnym nasileniem wystę- 
pują formy tektoniki solnej. Temperatury w tym regionie wynoszą od dwudziestu kilku stopni w zachodniej i południowej jego części do ponad $60^{\circ} \mathrm{C}$ w części centralnej. Mineralizacja wód termalnych wynosi do $35 \mathrm{~g} / \mathrm{dm}^{3}$, z tendencją malejącą w kierunku południowym i zachodnim. Prognozowana wydajność powinna być na przeważającym obszarze wysoka, a nawet bardzo wysoka, przekraczająca $100 \mathrm{~m}^{3} / \mathrm{h}$. Niższych wydajności można się spodziewać tylko na południowych i zachodnich krańcach wyróżnionego regionu. Spag skał dolnej kredy występuje na głębokości od ok. $300 \mathrm{~m}$ (południowe i zachodnie krańce regionu) do ok. $2100 \mathrm{~m}$ na obszarze położonym na północny zachód od Łodzi. Podobnie zmienna co do wartości i rozkładu przestrzennego jest miąższość utworów wodonośnych, która waha się od ok. 20 do ok. 200 m. Skały tego wieku to piaskowce z wkładkami mułowców formacji włocławskiej (ogniwa: pagórzańskie, goplańskie i kruszwickie) i mogileńskiej (ogniwa: gniewkowskie, żychlińskie i wierzchosławickie). Pierwsza formacja ujmuje osady baremu -albu, natomiast druga - walanżynu i hoterywu.

Subregion uniejowski (B1). Wschodnia część wyróżnionego subregionu to obszar występowania zjawisk tektoniki solnej. Dwie poduszki solne znajdują się w rejonie Turka i Poddębic. Subregion ten, rozciągający się na zachód i północny zachód od Łodzi, charakteryzuje wysoka temperatura wód termalnych wynosząca $50-70^{\circ} \mathrm{C}$ i niska oraz średnia ich mineralizacja (od kilku do $35 \mathrm{~g} / \mathrm{dm}^{3}$ ). Prognozowane wydajności $\mathrm{w}$ wielu miejscach przekraczają $100 \mathrm{~m}^{3} / \mathrm{h}$. Uwzględnienie rozkładu przestrzennego struktur solnych i nieciągłości tektonicznych przy wyborze miejsca ujęcia wód termalnych może mieć tutaj kluczowe znaczenie dla powodzenia inwestycji. Spąg utworów kredy znajduje się w opisywanym subregionie na głębokości od ok. $1100 \mathrm{~m}$ do ok. $2100 \mathrm{~m}$.

Subregion czarnkowsko-radomszczański (B2). Temperatura wód geotermalnych w basenie dolnej kredy wynosi tutaj od ok. 22 do ok. $40^{\circ} \mathrm{C}$, zaś ich mineralizacja dochodzi do $30 \mathrm{~g} / \mathrm{dm}^{3}$, przy czym najwyższe jej wartości występują w pobliżu kontaktu z subregionem B1. Prognozuje się wydajność studni od kilku do kilkudziesięciu $\mathrm{m}^{3} / \mathrm{h}$. Spag utworów kredy znajduje się tutaj na głębokości od ok. $300 \mathrm{~m}$ do ok. $1100 \mathrm{~m}$.

Region gorzowsko-poznański (C). Charakteryzują go wody termalne o mineralizacji od kilku do $35 \mathrm{~g} / \mathrm{l}$ i temperaturze od dwudziestu kilku do ok. $30^{\circ} \mathrm{C}$. Niestety spodziewane wydajności nie będą tutaj wysokie - co najwyżej do kilkunastu $\mathrm{m}^{3} / \mathrm{h}$, zwykle jednak pojedyncze $\mathrm{m}^{3} / \mathrm{h}$. Cechy te wynikają z płytkiego zalegania i małej miąższości poziomu wodonośnego. Spag utworów kredy leży tutaj na głębokości ok. $500 \mathrm{~m}$, a ich miąższość wynosi tylko ok. $20 \mathrm{~m}$. Miąższość warstwy wodonośnej nie przekracza kilkunastu metrów. Warstwę tę tworzą piaski i piaskowce albu (ogniwo kruszwickie).

Region zamojski (D). Jest to południowo-wschodni kraniec synklinorium koszalińsko-zamojskiego. Mineralizacja wód zbiornika dolnej kredy wynosi tutaj od ok. 20 do ok. $30 \mathrm{~g} / \mathrm{dm}^{3}$, a ich temperatura ok. $25-30^{\circ} \mathrm{C}$. Prognozowane potencjalne wydajności to maksymalnie kilkanaście $\mathrm{m}^{3} / \mathrm{h}$. Spag utworów kredy dolnej znajduje się na głębokości 500-700 m. Miąższość warstwy wodonośnej to tylko kilka metrów. Tworzą je piaski glaukonitowo-kwarcowe albu, które w niektórych miejscach regionu, jak wskazują dane $\mathrm{z}$ otworów wiertniczych, niestety mogły się nie zacho- wać. Stąd wyróżniony region należy traktować jako region o dosyć dużym ryzyku poszukiwań wód geotermalnych.

\section{BASEN HYDROGEOTERMALNY DOLNEJ JURY}

\section{Regiony z potencjałem ciepłowniczym}

Region piotrkowsko-radomski (A). Jego zachodnia część (ryc. 3), do okolic Rawy Mazowieckiej, to obszar intensywnej tektoniki solnej, której pochodnymi są rozległe formy antyklinalne, częściowo stowarzyszone z miejscami występowania czterech poduszek solnych o rozciagłości SENW. Zaangażowanie tektoniczne skał regionu na wschód od Rawy Mazowieckiej jest niewielkie. Strumień cieplny w regionie charakteryzują wartości niskie (wschodnia część) i średnie, nie przekraczające $80 \mathrm{~mW} / \mathrm{m}^{2}$ (zachodnia część regionu). Mineralizacja wód geotermalnych nie przekracza $35 \mathrm{~g} / \mathrm{dm}^{3}$, a ich temperatura zmienia się w zależności od lokalizacji - w szerokim zakresie od 40 do $70^{\circ} \mathrm{C}$. Potencjalne wydajności są tutaj bardzo wysokie, w wielu miejscach przekraczają $100 \mathrm{~m}^{3} / \mathrm{h}$. Wyjątkiem jest rejon Bełchatowa, gdzie należy się spodziewać znacznie niższych wartości wydajności. Spag utworów dolnej jury w regionie piotrkowsko-radomskim możemy nawiercić w szerokim przedziale głębokości tj. od ok. 1000 m do ok. 2700 m. Skałami wodonośnymi są głównie piaskowce hetangu, pliensbachu i toarku ujęte w formacje przysuską, drzewicką, ciechocińską i borucicką. Sumaryczna miąższość warstw wodonośnych waha się od 30 do blisko $600 \mathrm{~m}$.

Subregion łódzki (A1). Subregion ten wyróżnia się na tle pozostałych subregionów regionu piotrkowsko-radomskiego temperaturą wód termalnych przekraczającą $60^{\circ} \mathrm{C}$. Ich mineralizacja wynosi tutaj od $25-35 \mathrm{~g} / \mathrm{dm}^{3}$, a prognozowane wydajności przekraczają $100 \mathrm{~m}^{3} / \mathrm{h}$. Głębokość spagu skał dolnej jury wynosi w subregionie łódzkim ok. 2500-2700 m. Miąższość sumaryczna horyzontów wodonośnych waha się od ok. 200 do ok. 350 m.

Subregion piotrkowsko-garwoliński (A2). Subregion ten zajmuje większą cześć wyróżnionego regionu piotrkowsko-radomskiego. Temperatury wód termalnych zbiornika dolnej jury wynoszą od 40 do $60^{\circ} \mathrm{C}$, a ich mineralizacja od kilku do $35 \mathrm{~g} / \mathrm{dm}^{3}$. Poza rejonem Bełchatowa potencjalne wydajności studni są tutaj wysokie, przekraczają $100 \mathrm{~m}^{3} / \mathrm{h}$. Skały dolnej jury występują w tym subregionie na głębokości ok. 1200-2200 m. Miąższość sumaryczna horyzontów wodonośnych waha się od 30 do $400 \mathrm{~m}$.

Subregion jedliński (A3). Ten niewielki subregion, rozciąga się na północ od Radomia, wyróżnia się wyjątkową niską, nie przekraczającą $5 \mathrm{~g} / \mathrm{dm}^{3}$ mineralizacją wód termalnych. Ich temperatura wynosi tutaj ok. $45^{\circ} \mathrm{C}$, a potencjalne wydajności studni ok. $20-50 \mathrm{~m}^{3} / \mathrm{h}$. Spag utworów jury znajduje się na głębokości 1200-1500 m. Ich miąższość waha się od 50 do $200 \mathrm{~m}$, a łączna miąższość horyzontów wodonośnych to $30-150 \mathrm{~m}$.

Region poznańsko-kaliski (B). Region ten w całości znajduje się w obrębie synklinorium szczecińsko-miechowskiego, które w rejonie Poznania zawiera szereg drobniejszych struktur antyklinalnych i synklinalnych ułożonych kulisowo w stosunku do jego osi. Generalnie region poznańsko-kaliski charakteryzuje jednak niezaburzony układ warstw geologicznych. Jest on w całości poza obszarem występowania zjawisk tektoniki solnej, dlatego mineralizacja wód nie przekracza $35 \mathrm{~g} / \mathrm{dm}^{3}$, miejscami zbliżając się nawet do 


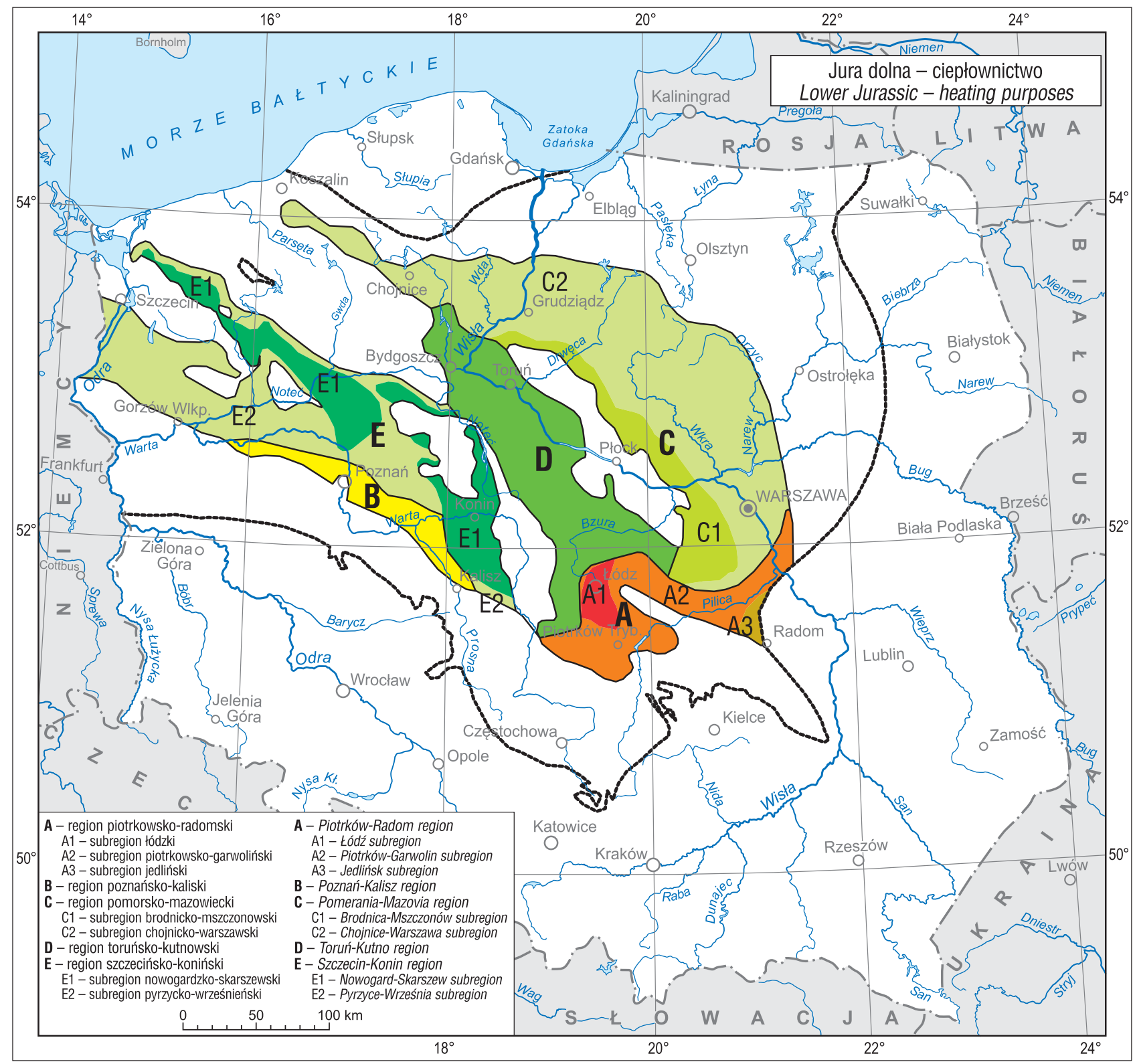

Ryc. 3. Regiony występowania wód geotermalnych w zbiorniku jury dolnej na Niżu Polskim, potencjalnie użytecznych do celów ciepłownictwa

Fig. 3. Regions of geothermal water occurrence in the Lower Jurassic reservoir in the Polish Lowlands, potentially useful for heating purposes

$5 \mathrm{~g} / \mathrm{dm}^{3}$. Temperatura wód termalnych wynosi $40-50^{\circ} \mathrm{C}$ i tylko w najbardziej na wschód wysuniętej części regionu zbliża się do $60^{\circ} \mathrm{C}$. Większość obszaru regionu poznańsko-kaliskiego cechuje wysoki strumień cieplny - powyżej $90 \mathrm{~mW} / \mathrm{m}^{2}$. Prognozowane wydajności studni na całym obszarze regionu przekraczają $100 \mathrm{~m}^{3} / \mathrm{h}$. Spąg utworów dolnej jury, których miąższość wynosi 300-400 m, znajduje się na głębokości od 1000 do $1400 \mathrm{~m}$. Sumaryczna miąższość warstw wodonośnych to $200-350 \mathrm{~m}$. Skały wodonośne dolnej jury tworzą piaskowce synemuru i hetangu (formacja ostrowiecka), pliensbachu (formacje łobeska i komorowska) oraz toarku (formacje ciechocińska i borucicka).

Region pomorsko-mazowiecki (C). Temperatura wód termalnych zbiornika dolnej jury wynosi $40-60^{\circ} \mathrm{C}$, przekracza te wartości tylko w wąskim pasie rozciagającym się na południowo-zachodnich krańcach regionu, co dało podstawy do podziału regionu pomorsko-mazowieckiego na dwa subregiony. Wyróżniony region charakteryzuje niski, a lokalnie nawet bardzo niski strumień cieplny. Mineralizacja wód termalnych jest średnia lub wysoka; w północno-wschodniej części regionu wynosi 30-60 g/dm³ $\mathrm{ku}$ południowemu zachodowi wzrasta do $100 \mathrm{~g} / \mathrm{dm}^{3}$. Spag utworów dolnej jury w regionie pomorsko-mazowieckim znajduje się na głębokości 1500-2700 m. Sumaryczna miąższość poziomów wodonośnych waha się od ok. $100 \mathrm{~m}$ do ok. $350 \mathrm{~m}$. Warstwy wodonośne to piaskowce formacji zagajskiej (synemur-hetang), a w części centralnej i południowej regionu - również piaskowce formacji ciechocińskiej (toark).

Subregion brodnicko-mszczonowski (C1). Subregion ten charakteryzują wody geotermalne basenu dolnej jury o temperaturze $60-70^{\circ} \mathrm{C}$ i mineralizacji od 50 do $100 \mathrm{~g} / \mathrm{dm}^{3}$ na jego zachodnich krańcach. Ich ujęcia powinna charakteryzować potencjalnie duża wydajność, przekraczająca $100 \mathrm{~m}^{3} / \mathrm{h}$. W wyróżnionym subregionie spag skał wodonośnych znajduje się na głębokości ok. 2400-2800 m, 
a sumaryczna miąższość horyzontów wodonośnych wynosi ok. 300-350 m.

Subregion chojnicko-warszawski (C2). W większej część subregionu wody termalne zbiornika dolnej jury charakteryzują temperatury $40-50^{\circ} \mathrm{C}$; tylko w pobliżu kontaktu z subregionem brodnicko-mszczonowskim ich wartości wzrastają do ok. $60^{\circ} \mathrm{C}$. Ich mineralizacja w zależności od miejsca wynosi ok. 40-80 g/ $\mathrm{dm}^{3}$. Potencjalne wydajności powinny być zbliżone do tych charakteryzujących subregion C1, czyli miejscami przekraczać $100 \mathrm{~m}^{3} / \mathrm{h}$. Spąg utworów dolnej jury w znajduje się na głębokości 1500$2500 \mathrm{~m}$. Sumaryczna miąższość poziomów wodonośnych waha się tutaj od ok. $100 \mathrm{~m}$ do ok. $250 \mathrm{~m}$.

Region toruńsko-kutnowski (D). Jego część na północ od Łodzi i na zachód od Wisły to obszar intensywnej tektoniki solnej, z wysadami solnymi i szeregiem stref uskokowych równoległych do rozciągłości antyklinorium środkowopolskiego, które przebiega przez centralną część wyróżnionego regionu i którego południowo-zachodnie i północno-wschodnie fragmenty obejmują też odpowiednio skrzydła synklinorium szczecińsko-miechowskiego i synklinorium koszalińsko-zamojskiego. Intensywna tektonika solna i szereg głęboko założonych nieciągłości tektonicznych narzuca ostrożność w przyjmowaniu za obowiązujące $\mathrm{w}$ każdym miejscu regionu przedstawionych tutaj wartości mineralizacji wód termalnych. W niektórych miejscach regionu toruńsko-kutnowskiego mogą one przekraczać $100 \mathrm{~g} / \mathrm{dm}^{3}$. W trzech miejscach wysady solne przebijają skały mezozoiczne. Skomplikowana tektonika regionu toruńsko-kutnowskiego z pewnością wskazuje na potrzebę jej szczegółowszego rozpoznania i uwzględnienia przy planowaniu otworów geotermalnych. Temperatura wód termalnych zbiornika dolnej jury wynosi $60-70^{\circ} \mathrm{C}$, spada do niższych wartości tylko na niewielkich obszarach wewnątrz regionu i na jego krańcach. Mineralizacja wód termalnych waha się w obrębie regionu od 40 do $100 \mathrm{~g} / \mathrm{dm}^{3}$; tylko na trzech niewielkich obszarach w centralnej części regionu spada nieco poniżej $35 \mathrm{~g} / \mathrm{dm}^{3}$. W całym regionie potencjalne prognozowane wydajności studni są wysokie, przekraczające $100 \mathrm{~m}^{3} / \mathrm{h}$. Spąg skał dolnej jury leży na bardzo zróżnicowanych głębokościach - od ok. 1600 do ok. $3100 \mathrm{~m}$. Łączna miąższość poziomów wodonośnych jest zmienna - 50-800 m. Skały, w których znajdują się poziomy wodonośne zbiornika dolnej jury, to piaskowce formacji skłobskiej (synemur-hetang), gielniowskiej i drzewickiej (pliensbach-synemur) oraz borucickiej (toark).

Region szczecińsko-koniński (E). To pas basenu dolnej jury nie tworzący jednego zwartego obszaru. Miejsca nieciągłości to głównie miejsca, gdzie mineralizacja wód przekracza $100 \mathrm{~g} / \mathrm{dm}^{3}$. Sa to przede wszystkim rejony występowania antyklin rozwiniętych nad poduszkami i wysadami solnymi. Cały region znajduje się w obrębie strefy, w której występują formy związane z tektoniką solną. Strumień cieplny jest na obszarze wyróżnionego regionu średni i wysoki, w jego południowej części przekracza $90 \mathrm{~mW} / \mathrm{m}^{2}$. Temperatura wód termalnych wynosi od 40 do ok. $70^{\circ} \mathrm{C}$, przy czym temperatury przekraczające $60^{\circ} \mathrm{C}$ są charakterystyczne dla części zbiornika geotermalnego zajmujących północne i wschodnie fragmenty regionu szczecińsko-konińskiego, co dało tutaj podstawę do wyróżnienia subregionu E1. Mineralizacja wód termalnych niemal na całym obszarze regionu szczecińsko-konińskiego wynosi od 35 do $100 \mathrm{~g} / \mathrm{dm}^{3}$. Cechą pozytywną, charakterystyczną dla całego regionu, jest prognozowana wysoka wydajność studni, przekraczająca $100 \mathrm{~m}^{3} / \mathrm{h}$. Spag skał dolnej jury występuje w opisywanym regionie na głębokościach od ok. 1000 do ok. 2700 m. Łączna miąższość poziomów wodonośnych to ok. 70-400 m. Skały, w których znajdują się poziomy wodonośne zbiornika dolnej jury, to piaskowce formacji skłobskiej (synemur-hetang), gielniowskiej i drzewickiej (pliensbach-synemur) oraz borucickiej (toark).

Subregion nowogardzko-skarszewski (E1). Cechą charakterystyczną tego subregionu są temperatury wód termalnych zbiornika dolnej jury przekraczające $60^{\circ} \mathrm{C}$, miejscami dochodzące nawet do $90^{\circ} \mathrm{C}$. Ich mineralizacja zmienia się w przedziale $35-100 \mathrm{~g} / \mathrm{dm}^{3}$. Niższe jej wartości mogą charakteryzować tylko obszar w pobliżu ujścia Gwdy do Noteci. Spąg skał dolnej jury znajduje się na głębokości 2100 $2700 \mathrm{~m}$.

Subregion pyrzycko-wrześnieński (E2). Jest to część regionu E, rozciagająca się od doliny dolnej Odry do okolic Wrześni, która charakteryzuje się temperaturami wód zbiornika termalnego dolnej jury od 40 do $60^{\circ} \mathrm{C}$. Takie wartości temperatur występują również w bardzo wąskim, zaliczonym także do tego subregionu, pasie, który przylega od północy do subregionu E1, jak również w niewielkiej enklawie subregionu E2, która znajduje się na wschód od Kalisza. Mineralizacja wód geotermalnych w subregionie E2 wynosi ok. 40-80 g/dm ${ }^{3}$. Spag warstw dolnej jury występuje tutaj na głębokości ok. 1300-2100 m.

\section{Regiony z potencjałem w zakresie rekreacji}

Region warmińsko-mazowiecki (A). Region ten rozciąga się od granicy Polski z Federacją Rosyjską na północy do okolic Garwolina na południu (ryc. 4). Wody termalne zbiornika dolnej jury o temperaturze $30-35^{\circ} \mathrm{C}$, a w obrębie subregionu A1 o temperaturze ok. $40^{\circ} \mathrm{C}$, charakteryzują się również zmienną mineralizacją - od pojedynczych $\mathrm{g} / \mathrm{dm}^{3}$, w pasie między Łomżą a Węgrowem, do $35 \mathrm{~g} / \mathrm{dm}^{3}$ wzdłuż zachodniej granicy regionu. W całym regionie wyraźnie uwidacznia się zależność, że ku jego zachodowi wzrost temperatury wód termalnych jest związany ze wzrostem ich mineralizacji. Spąg utworów jury dolnej znajduje się głębokości ok. 600-1400 m. Łączna miąższość poziomów wodonośnych waha się w przedziale 30-150 m. Poziomy te znajdują się głównie w piaskowcach formacji olsztyńskiej (pliensbach).

Subregion wielbarsko-maciejowicki (A1). Subregion ten obejmuje południowo-zachodnie krańce regionu warmińsko-mazowieckiego, wyróżnia się najwyższymi temperaturami wód termalnych, które wynoszą $40-45^{\circ} \mathrm{C}$. Mineralizacja wód termalnych jest na tym obszarze w skali regionu również najwyższa - wynosi ok. $30-35 \mathrm{~g} / \mathrm{dm}^{3}$.

Subregion bartoszycko-garwoliński (A2). Obejmuje on pozostałą, zdecydowanie większą część regionu warmińsko-mazowieckiego. Temperatury wód termalnych w jego wschodniej części wynoszą ok. $20^{\circ} \mathrm{C}$ i stopniowo rosną ku zachodowi do maksymalnie $40^{\circ} \mathrm{C}$. Mineralizacja spada do pojedynczych gramów na $\mathrm{dm}^{3}$ na wschodnich krańcach subregionu, gdzie niestety i ich temperatura jest najniższa.

Region pabianicko-radomski (B). Wody termalne z północnej i zachodniej części tego regionu mają temperatury przekraczające $40^{\circ} \mathrm{C}$, a w okolicach Łodzi nawet $60^{\circ} \mathrm{C}$. Centralna i południowa część regionu charakteryzuje się jednak temperaturami wód termalnych zbiornika dolnej jury $20-35^{\circ} \mathrm{C}$. W tej też części najniższa jest ich mineralizacja, wynosząca od kilku do kilkunastu $\mathrm{g} / \mathrm{dm}^{3}$. Minerali- 


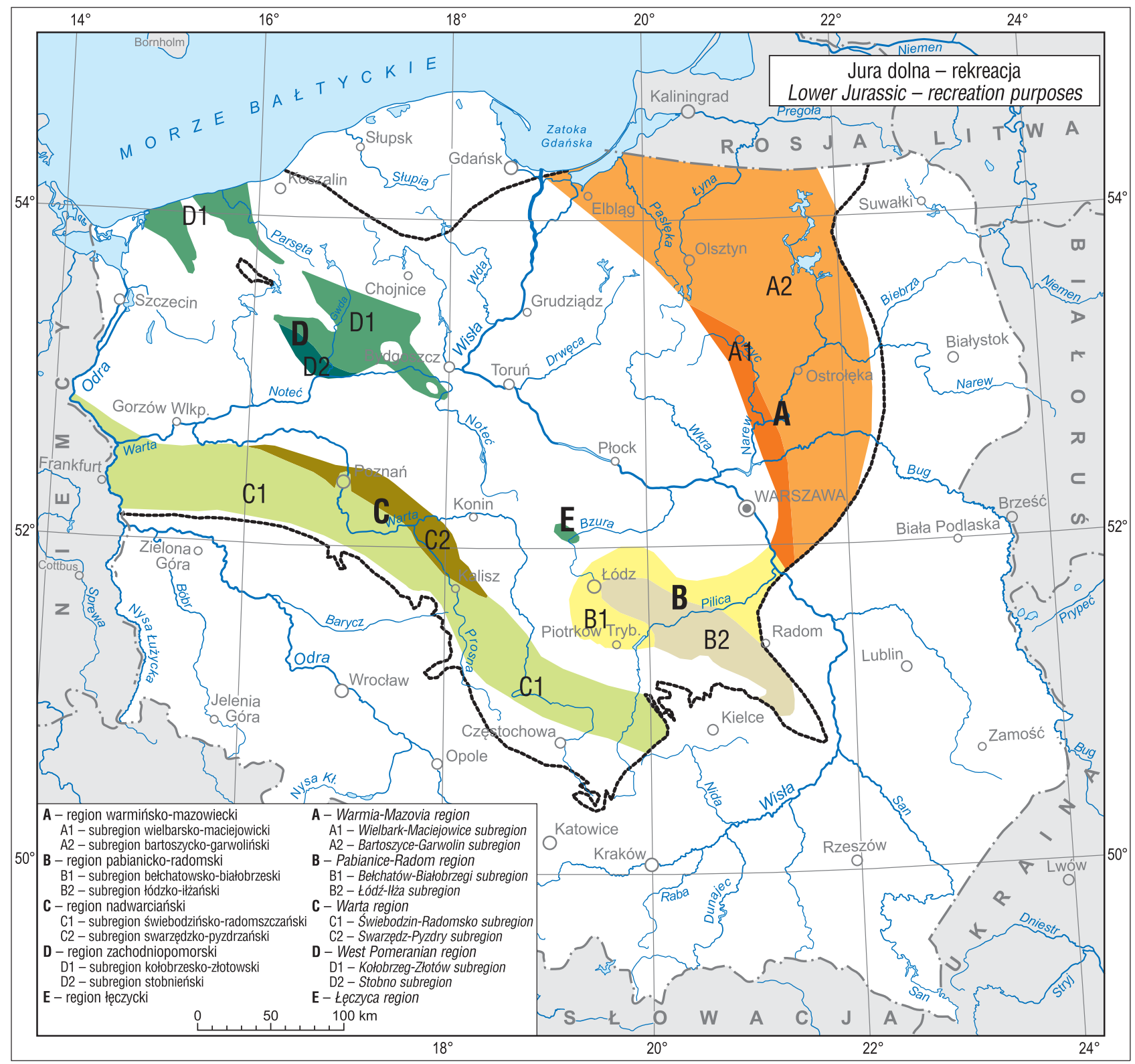

Ryc. 4. Regiony występowania wód geotermalnych w zbiorniku jury dolnej na Niżu Polskim, potencjalnie użytecznych do celów rekreacji Fig. 4. Regions of geothermal water occurrence in the Lower Jurassic reservoir in the Polish Lowlands, potentially useful for recreation purposes

zacja ta jest wyższa (do $\left.35 \mathrm{~g} / \mathrm{dm}^{3}\right)$ na obszarach, gdzie temperatura przekracza $40^{\circ} \mathrm{C}$. Skały dolnojurajskiego basenu hydrogeotermalnego to piaskowce przysuskiej formacji rudonośnej (hetang-synemur), mułowce formacji gielniowskiej (pliensbach dolny), piaskowce formacji drzewickiej (pliensbach górny) i ciechocińskiej (toark dolny), a także piaskowce formacji borucickiej (toark górny). Sumaryczna miąższość poziomów wodonośnych waha się w granicach 30-500 m. Spag tych skał znajduje się na głębokości od ok. 1000 m (obszar między Radomiem a Piotrkowem Trybunalskim) do ok. $2500 \mathrm{~m}$ (rejon na południe od Łodzi).

Subregion bełchatowsko-białobrzeski (B1). Subregion ten charakteryzują wody geotermalne zbiornika dolnej jury o temperaturze $40-60^{\circ} \mathrm{C}$. Wody te w większości miejsc wyróżnionego subregionu cechuje mineralizacja $5-35 \mathrm{~g} / \mathrm{dm}^{3}$, może być niższa od $5 \mathrm{~g} / \mathrm{dm}^{3}$ tylko na niewielkich obszarach położonych na zachód od Piotrkowa Trybunalskiego i na północny wschód od Tomaszowa Mazowieckiego. W pobliżu tego pierwszego miasta prognozowane wydajności studni mogą być niższe od tych spodziewanych w innych miejscach regionu, gdzie wynoszą od kilkudziesięciu do ponad $100 \mathrm{~m}^{3} / \mathrm{h}$. Spag zbiornikowych skał dolnej jury znajduje na głębokości ok. 1500-2500 m.

Subregion łódzko-iłżański (B2). Subregion ten rozciąga się wąskim pasem równoległym do rozciagłości antyklinorium środkowopolskiego, w obrębie którego się znajduje, od okolic Łodzi do północnych rejonów Ostrowca Świętokrzyskiego. Spotkamy tutaj wody termalne zbiornika dolnej jury o temperaturach $20-40^{\circ} \mathrm{C}$, wzrastających w kierunku granicy z subregionem bełchatowsko-białobrzeskim. Ich mineralizacja wynosi tylko $4-10 \mathrm{~g} / \mathrm{dm}^{3}$, a w południowej części subregionu spada poniżej $4 \mathrm{~g} / \mathrm{dm}^{3}$. Spąg utworów dolnej jury w wyróżnionym subregionie znajduje się na głębokości od ok. $1000 \mathrm{~m}$ do ok. $1500 \mathrm{~m}$.

Region nadwarciański (C). Temperatury wód termalnych wzrastają tutaj stopniowo ku północnemu wschodowi do ok $50^{\circ} \mathrm{C}$ w okolicach Poznania i Kalisza. W części 
położonej na monoklinie przedsudeckiej, a także w okolicach Włoszczowej wynoszą one jednak tylko $20-30^{\circ} \mathrm{C}$. Podobna zależność dotyczy również stopnia mineralizacji wód termalnych zbiornika dolnej jury na obszarze wyróżnionego regionu, który spada wraz ze spadkiem temperatury od $35 \mathrm{~g} / \mathrm{dm}^{3}$ do pojedynczych $\mathrm{g} / \mathrm{dm}^{3}$. Wydajność prawie na całym obszarze powinna być wysoka; spada do pojedynczych $\mathrm{m}^{3} / \mathrm{h}$ tylko na jego południowo-wschodnich krańcach. Wysokie wartości strumienia cieplnego charakteryzują zachodnią część regionu nadwarciańskiego. Głębokość spagu skał dolnej jury zmienia się od ok. $450 \mathrm{~m}$ do ok. $1700 \mathrm{~m}$. Łączna miąższość warstw wodonośnych to ok. 50-450 m. W części regionu z największymi miąższościami dolnej jury poziomy wodonośne obejmują warstwy piaskowców formacji ostrowieckiej (synemur-hetang), łobeskiej (pliensbach dolny), komorowskiej (pliensbach górny), ciechocińskiej (toark dolny) i borucickiej (toark górny).

Subregion świebodzińsko-radomszczański (C1). Jego charakterystyczną cechą jest najwyższa w regionie nadwarciańskim temperatura wód termalnych zbiornika dolnej jury, która wynosi od 40 do $60^{\circ} \mathrm{C}$ (na północ od Kalisza). $\mathrm{Na}$ większości jego obszaru należy spodziewać się wód o mineralizacji 20-35 g/l. W najbliższym sąsiedztwie Poznania skały zbiornika dolnej jury są znacząco zaburzone tektonicznie. Głębokość spagu utworów dolnej jury w całym omawianym subregionie zmienia się od ok. $1100 \mathrm{~m}$ do ok. $1700 \mathrm{~m}$.

Subregion swarzędzko-pyzdrzański (C2). Wody termalne zbiornika dolnej jury mają tutaj temperaturę od 20 do $40^{\circ} \mathrm{C}$. Południowa część subregionu charakteryzuje się wodami geotermalnymi o mineralizacji poniżej $5 \mathrm{~g} / \mathrm{dm}^{3}$. W północno-zachodniej części subregionu mineralizacja ta wzrasta stopniowo do $35 \mathrm{~g} / \mathrm{dm}^{3}$. Podobnego jej wzrostu należy spodziewać się na niewielkim obszarze położonym ok. 50 km na południowy wschód od Kalisza. Spag utworów dolnej jury znajduje się na głębokości od ok. 450-1100 m. W okolicach Piotrkowa Trybunalskiego miąższość utworów tego piętra radykalnie się zmniejsza, a miejscami utwory te zanikaja.

Region zachodniopomorski (D). Obejmuje on trzy odrębne obszary na Pomorzu Zachodnim, leżące blisko siebie. Południowo wschodnia enklawa regionu to obszar intensywnej tektoniki solnej. W regionie zachodniopomorskim wody termalne zbiornika dolnej jury mają temperaturę tylko $21-30^{\circ} \mathrm{C}$. Na niewielkim obszarze, w okolicy ujścia Gwdy do Noteci, zdefiniowanym niżej jako subregion D2, temperatura ta może być zasadniczo wyższa, sięgając nawet $60^{\circ} \mathrm{C}$. Należy się tam też spodziewać największych zmian mineralizacji wód termalnych - od pojedynczych $\mathrm{g} / \mathrm{dm}^{3}$ w jego północnej części do $35 \mathrm{~g} / \mathrm{dm}^{3}$ na południowych krańcach. Spag utworów dolnej jury znajduje się na głębokości ok. 700-1500 m. Łączna miąższość poziomów wodonośnych wynosi ok. 400-600 m. Poziomy te znajdują się w piaskowcach hetangu (formacja skłobska), synemuru (formacja ostrowiecka), pleinsbachu (formacje łobeska i komorowska) i górnego toarku (formacja borucicka). Potencjalna wydajność na całym obszarze opisywanego regionu jest wysoka - od kilkudziesięciu do ponad $100 \mathrm{~m}^{3} / \mathrm{h}$.

Subregion kołobrzesko-złotowski (D1). Subregion ten tworzą trzy odizolowane fragmenty regionu D, w obrębie których temperatura wód termalnych zbiornika dolnej jury jest dosyć niska $\left(20-30^{\circ} \mathrm{C}\right)$, tylko miejscami dochodzi do $40^{\circ} \mathrm{C}$ (okolice Piły i Gryfic). Mineralizacja tych wód jest tutaj niewielka, waha się od kilku do kilkunastu $\mathrm{g} / \mathrm{dm}^{3}$. Spąg zbiornika znajduje się na głębokości ok. 700-1280 m.

Subregion stobnieński (D2). Ten wąski pas na południe od Piły to jedyny obszar regionu zachodniopomorskiego, gdzie temperatura wód geotermalnych zbiornika dolnej jury wynosi od 40 do $60^{\circ} \mathrm{C}$. Jednak, jak już wspomniano powyżej, wzrostowi temperatury będzie towarzyszyć wzrost mineralizacji do przyjętej tutaj wartości granicznej $35 \mathrm{~g} / \mathrm{dm}^{3}$. Subregion jestograniczony od północy niewielką poduszką solną (rejon Piły), a od południowego zachodu bardziej rozległą strukturą o tym samym charakterze, której południowy skraj znajduje się w rejonie Trzcianki. Spag zbiornika hydrogeotermalnego dolnej jury leży tutaj na głębokościach od ok. 1000 do ok. 1500 m.

Region lęczycki (E). Jest to niewielka enklawa, gdzie mineralizacja wód jest nieco niższa od $35 \mathrm{~g} / \mathrm{dm}^{3}$, a ich temperatura to ok. $50-60^{\circ} \mathrm{C}$. Obszar ten, rozciagający się na północ od Łęczycy, jest dla utworów jury fragmentem regionalnego depocentrum. Strop utworów dolnej jury zalega w regionie łęczyckim na głębokości ok. 1500-2100 m. Łączna miąższość poziomów wodonośnych wynosi ok. 550-700 m. Formacje wodonośne są jednak w wielu miejscach profilu przeławicane utworami ilastymi. Stąd prognozowana wydajność w wyróżnionym regionie nie przekracza kilkudziesięciu $\mathrm{m}^{3} / \mathrm{h}$.

\section{BASEN HYDROGEOTERMALNY DOLNEGO TRIASU}

\section{Regiony z potencjałem ciepłowniczym}

Region przasnysko-kozienicki (A). Ten wąski pas basenu hydrogeotermalnego dolnego triasu rozciaga się od okolic Przasnysza do terenów położonych na północny wschód od Radomia (ryc. 5). Występują tutaj wody termalne o temperaturze $40-50^{\circ} \mathrm{C}$ i mineralizacji $50-100 \mathrm{~g} / \mathrm{dm}^{3}$. Prognozowane wydajności studni w regionie przasnysko-kozienickim nie przekraczają kilkunastu $\mathrm{m}^{3} / \mathrm{h}$. Głębokość zalegania spagu skał dolnego triasu wynosi ok. $1700 \mathrm{~m}$. Sumaryczna miąższość poziomów wodonośnych to ok. 40-100 m. Poziomy te wypełniaja piaskowce i mułowce występujące w obrębie klastycznych utworów pstrego piaskowca dolnego i środkowego.

Region opoczniański (B). Mineralizacja wód termalnych w jego centrum i w części południowo-wschodniej wynosi od 30 do $50 \mathrm{~g} / \mathrm{dm}^{3}$. Na pozostałym obszarze dochodzi do $100 \mathrm{~g} / \mathrm{dm}^{3}$. Podobny trend dotyczy również rozkładu temperatur wód termalnych. Temperatury te zbliżają się do $60^{\circ} \mathrm{C}$ na północno-zachodnich krańcach regionu opoczniańskiego, a maleją do $40^{\circ} \mathrm{C}$ w kierunku południowo wschodnim. Prognozowana wydajność studni to ok. $20-50 \mathrm{~m}^{3} / \mathrm{h}$. Spag utworów dolnego triasu w regionie opoczniańskim znajduje się na głębokości od ok. 1200 do ponad $3028 \mathrm{~m}$. Miąższość sumaryczna horyzontów wodonośnych, które znajdują się tutaj w piaskowcach dolnego i środkowego piaskowca, a także w dolnym recie (warstwy z wąchocka i warstwy z radoszyc), wynosi ok. 150-400 m.

Region sycowski (C). Temperatura wód termalnych zmienia się w kierunku północno-zachodnich granic regionu od 40 do $60^{\circ} \mathrm{C}$. Temperatur przekraczających nieco $60^{\circ} \mathrm{C}$ należy oczekiwać na niewielkim obszarze położonym na wschód od doliny górnej Prosny. Mineralizacja wód termalnych jest $\mathrm{w}$ tym regionie dosyć wysoka, waha się od 


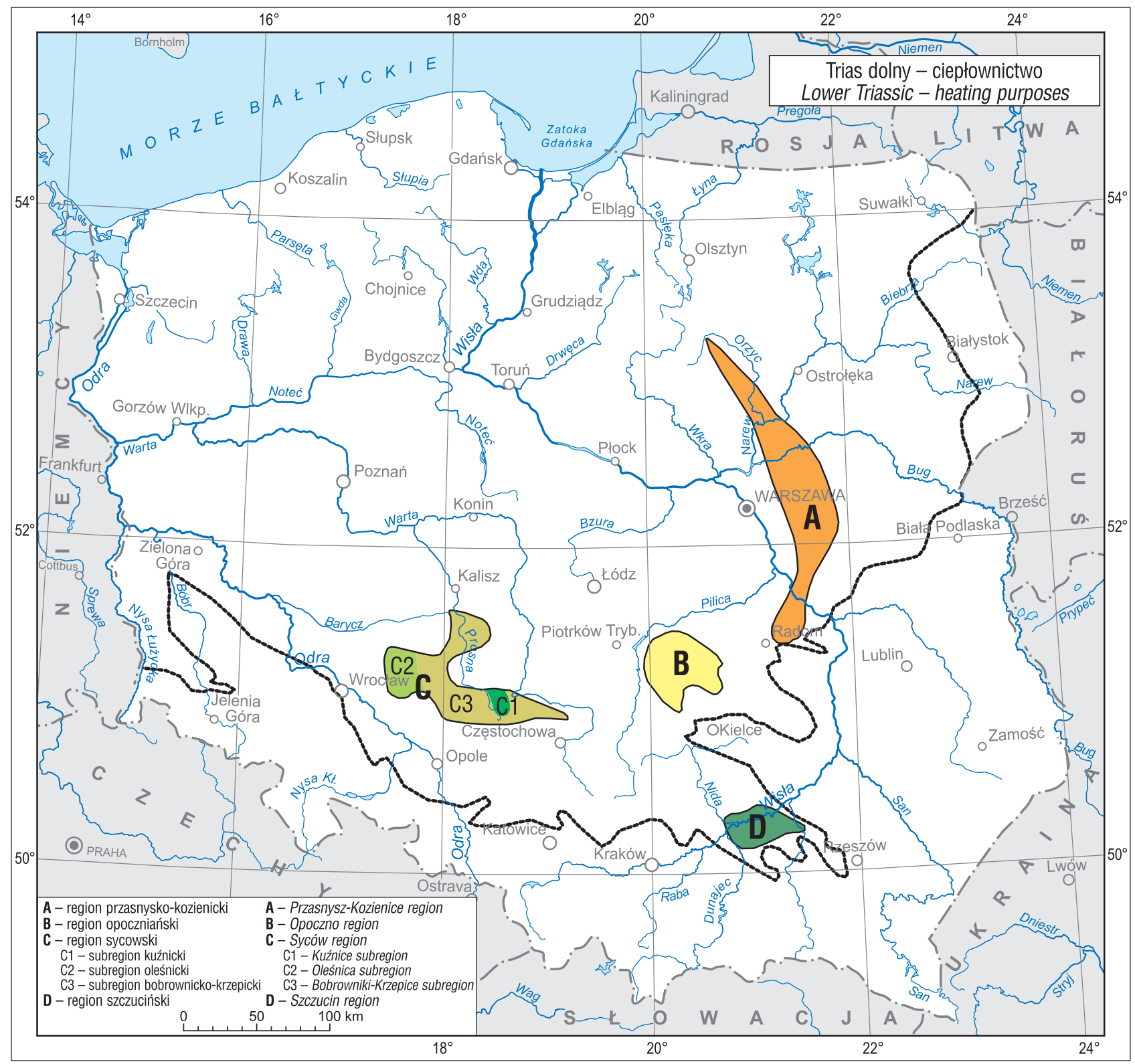

Ryc. 5. Regiony występowania wód geotermalnych w zbiorniku triasu dolnego na Niżu Polskim, potencjalnie użytecznych do celów ciepłownictwa

Fig. 5. Regions of geothermal water occurrence in the Lower Triassic reservoir in the Polish Lowlands, potentially useful for heating purposes

40 do $100 \mathrm{~g} / \mathrm{dm}^{3}$. Tylko wysunięty w kierunku Wrocławia niewielki fragment regionu cechuje wyraźnie niższy stopień mineralizacji tych wód, tj. 20-35 g/dm³ . Prognozowane wydajności studni to $10-50 \mathrm{~m}^{3} / \mathrm{h}$. Spąg utworów dolnego triasu znajduje się w regionie sycowskim na głębokości od ok. 1200 m do ok. 2700 m. Sumaryczna miąższość horyzontów wodonośnych zbiornika dolnego triasu to ok. 100 $400 \mathrm{~m}$. Skały zbiornikowe tworzą tutaj piaskowce dolnego i środkowego pstrego piaskowca.

Subregion kuźnicki (C1) jest to miejsce, gdzie na małym obszarze regionu sycowskiego temperatura wód geotermalnych zbiornika dolnego triasu może nieznacznie przekroczyć $60^{\circ} \mathrm{C}$. Zasolenie tych wód będzie jednak dosyć wysokie tj. od ok. 50 do ok. $100 \mathrm{~g} / \mathrm{dm}^{3}$. Spag utworów dolnego triasu znajduje się na głębokości 2500-2700 m.

Subregion oleśnicki (C2). Ten niewielki obszar cechuje mineralizacja wód geotermalnych niższa od $35 \mathrm{~g} / \mathrm{dm}^{3}$. Jednak ich temperatura niewiele będzie przekraczać $40^{\circ} \mathrm{C}$, gdyż spag skał zbiornikowych znajduje się tutaj tylko na głębokości zbliżonej do $1200 \mathrm{~m}$.

Subregion bobrownicko-krzepicki (C3) to pozostała część regionu sycowskiego, gdzie wody geotermalne zbiornika dolnego triasu, o stosunkowo wysokiej mineralizacji (40-100 g/dm ${ }^{3}$, będzie cechować temperatura $40-60^{\circ} \mathrm{C}$. Niestety, jak w większości innych miejsc mezozoicznych basenów hydrogeotermalnych na Niżu Polskim, wzrostowi temperatury towarzyszy tutaj wzrost mineralizacji wód.

Region szczuciński (D). Mineralizacja wód zbiornika dolnego triasu jest tutaj umiarkowana. Jej wartość to 10 $20 \mathrm{~g} / \mathrm{dm}^{3}$. Wody te mają temperaturę $45-50^{\circ} \mathrm{C}$. Wydajność to nie więcej niż ok. $10-15 \mathrm{~m}^{3} / \mathrm{h}$. Skały triasu charakteryzuje duża zmienność facjalna i brak precyzyjnej stratygrafii. Pakiet utworów piaszczystych przykrytych miejscami węglanami retu/wapienia muszlowego reprezentuje głównie dolny pstry piaskowiec. Miąższość sumaryczna poziomów 
wodonośnych to maksymalnie $20 \mathrm{~m}$. Spąg utworów triasowych znajduje się na głębokości 1200-1500 m.

\section{Regiony $\mathrm{z}$ potencjałem $\mathrm{w}$ zakresie rekreacji}

Region podlaski (A). Region ten rozciąga się południkowo między doliną dolnej Biebrzy a Siedlcami (ryc. 6). Mineralizacja wód geotermalnych zbiornika dolnego triasu wynosi tutaj od pojedynczych $\mathrm{g} / \mathrm{dm}^{3}$ (część południowo-wschodnia regionu) do $35 \mathrm{~g} / \mathrm{dm}^{3}$. Ich temperatura niewiele przekracza $20^{\circ} \mathrm{C}$, do $40^{\circ} \mathrm{C}$ zbliża tylko w południowo-zachodniej części wyróżnionego regionu, gdzie i mineralizacja wód będzie jednak już znacząca $\left(30-35 \mathrm{~g} / \mathrm{dm}^{3}\right)$. Strop skał dolnego triasu znajduje się w regionie podlaskim na głębokości ok. 1000-2000 m. Łączna miąższość poziomów wodonośnych w basenie dolnego triasu nie przekracza $50 \mathrm{~m}$. Poziomy te znajdują się w mułowcach i wkładkach piaskowców dolnego i środkowego pstrego piaskowca. Prognozowane wydajności studni to od kilku do najwyżej ok. $20 \mathrm{~m}^{3} / \mathrm{h}$.
Subregion tykocińsko-międzyrzecki (A1). Zajmuje on ponad $80 \%$ obszaru regionu podlaskiego. Mineralizacja wód wynosi tutaj powyżej $5 \mathrm{~g} / \mathrm{dm}^{3}$, a ich temperatura wyraźnie przekracza $20^{\circ} \mathrm{C}$, jednak tylko na południowym zachodzie wynosi ok. $40^{\circ} \mathrm{C}$.

Subregion łosicki (A2). Subregion ten wyróżnia bardzo niska mineralizacja wód termalnych, poniżej $5 \mathrm{~g} / \mathrm{dm}^{3}$. Ich temperatura tylko nieznacznie przekracza $20^{\circ} \mathrm{C}$, a prognozowane wydajności będą należeć też do najniższych w regionie.

Region szczuciński (B). Mineralizacja wód zbiornika dolnego triasu jest tutaj umiarkowana $\left(10-20 \mathrm{~g} / \mathrm{dm}^{3}\right)$. Wody te mają temperaturę $40-50^{\circ} \mathrm{C}$. Prognozowana wydajność to od kilku do ok. $10-15 \mathrm{~m}^{3} / \mathrm{h}$. Skały triasu charakteryzuje duża zmienność oboczna. Sumaryczna miąższość poziomów wodonośnych to nie więcej niż 20 m. Spag utworów triasowych znajduje się na głębokości 1000-1500 m.

Region mniowski (C). Prognozowane wydajności w regionie mniowskim to od kilku do maksymalnie $20-30 \mathrm{~m}^{3} / \mathrm{h}$.

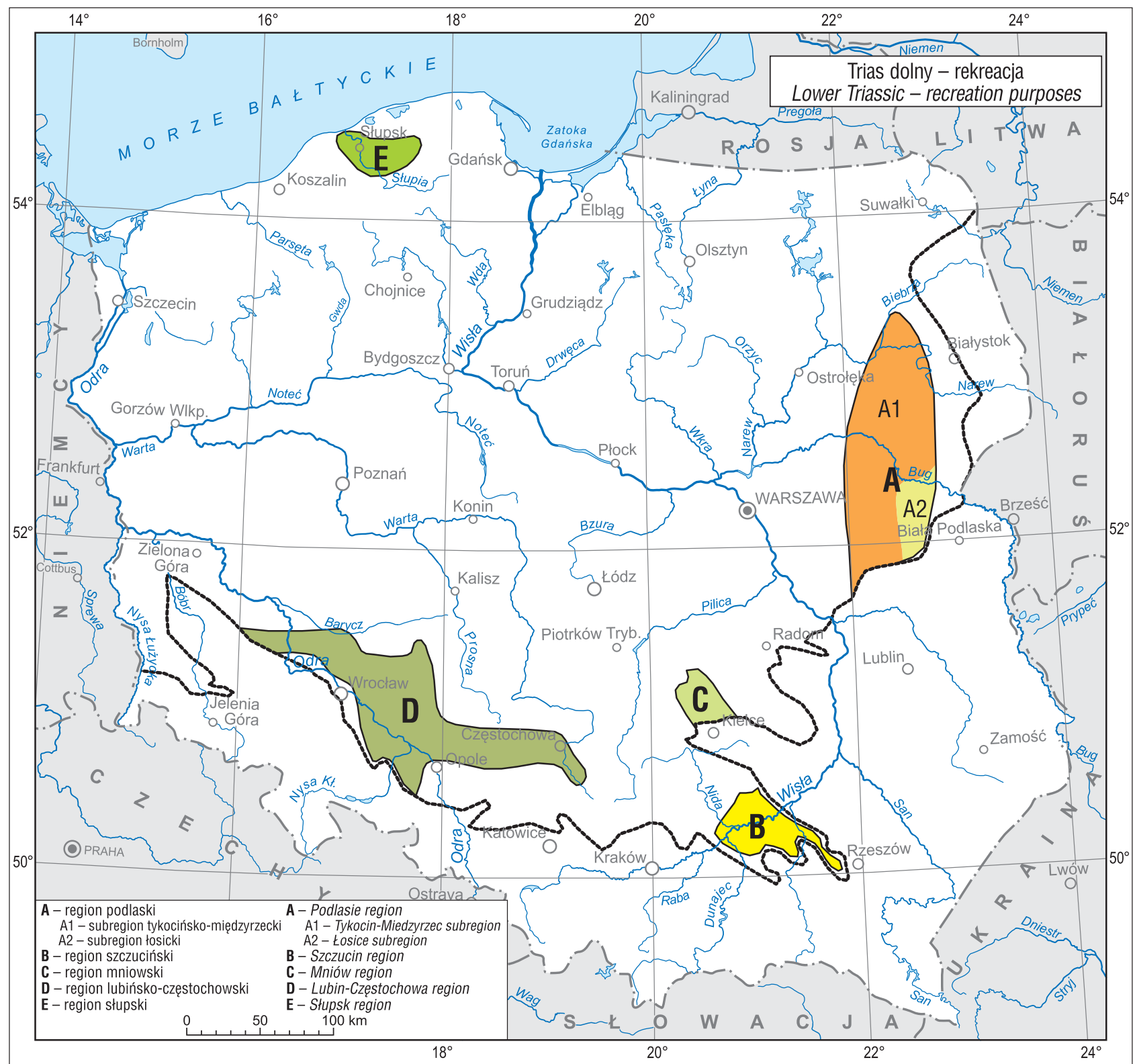

Ryc. 6. Regiony występowania wód geotermalnych w zbiorniku triasu dolnego na Niżu Polskim, potencjalnie użytecznych do celów rekreacji Fig. 6. Regions of geothermal water occurrence in the Lower Triassic reservoir in the Polish Lowlands, potentially useful for recreation purposes 
Temperatura wód termalnych wzrasta w kierunku północnym, który jest kierunkiem zapadania warstw triasowych, od 20 do ok. $40^{\circ} \mathrm{C}$. Ich mineralizacja też będzie wzrastać w tym kierunku od kilkunastu do $35 \mathrm{~g} / \mathrm{dm}^{3}$. Strop skał dolnego triasu zanurza się do głębokości ok. 1600 m. Sumaryczna miąższość warstw wodonośnych to 30-100 m. Warstwy te znajdują się głównie w piaszczystych mułowcach i piaskowcach pstrego piaskowca środkowego i górnego.

Region lubińsko-częstochowski (D). Temperatury wód zbiornika triasowego wzrastają tutaj ku północy z ok. 20 do ok. $40^{\circ} \mathrm{C}$, przekraczają o kilka stopni tę wartość tylko na obszarze położonym na wschód od Wrocławia. Podobny trend dotyczy też stopnia mineralizacji wód termalnych, która zmienia się od 5 do $35 \mathrm{~g} / \mathrm{dm}^{3}$. Prognozowane wydajności to maksymalnie $30-50 \mathrm{~m}^{3} / \mathrm{h}$. Spąg skał dolnego triasu znajduje się na głębokości ok. 800-1500 m. Łączna miąższość poziomów wodonośnych to ok. $150 \mathrm{~m}$. Poziomy te są zlokalizowane głównie w piaskowcach górnej części profilu dolnego pstrego piaskowca oraz w dolnej części profilu pstrego piaskowca środkowego.

Region słupski (E). Jest to niewielka enklawa basenu hydrogeotermalnego dolnego triasu, gdzie mineralizacja wód termalnych w stosunku do otoczenia spada poniżej $35 \mathrm{~g} / \mathrm{dm}^{3}$. Należy się spodziewać tam jednak mineralizacji nie niższej niż $20 \mathrm{~g} / \mathrm{dm}^{3}$. Temperatura wód termalnych jest niska, gdyż dochodzi maksymalnie tylko do $30^{\circ} \mathrm{C}$. Prognozowane wydajności to kilkanaście $\mathrm{m}^{3} / \mathrm{h}$, maksymalnie 20-30 $\mathrm{m}^{3} / \mathrm{h}$. Strop skał triasu znajduje się na głębokości
700-800 m. Łączna miąższość horyzontów wodonośnych, które znajdują się we wkładkach piaskowców dolnego i prawdopodobnie środkowego pstrego piaskowca, to ok. $100 \mathrm{~m}$.

\section{RANKING REGIONÓW GEOTERMALNYCH}

Przeprowadzone tutaj wartościowanie wskazuje, że w zakresie geotermii związanej z wodami o temperaturze wyższej od $60^{\circ} \mathrm{C}$, potencjał ciepłowniczy ogranicza się tylko do regionów, dla których zdefiniowano przydatność umiarkowaną i niską (tab. 1). Nie wyróżniono żadnego regionu lub subregionu o wysokiej przydatności. W kolejności od obszarów najwyżej punktowanych, umiarkowaną przydatnością cechują się subregiony nowogardzko-skarszewski (E1, zbiornik jury dolnej) i łódzki (A1, zbiornik jury dolnej), region toruńsko-kutnowski (D, zbiornik jury dolnej) oraz subregion goplańsko-uniejowski (B, zbiornik kredy dolnej). W pozostałych jednostkach przydatność tę określono jako niską. W zakresie geotermii wspomaganej, czyli tej opartej na wodach o temperaturze $40-60^{\circ} \mathrm{C}$, wydzielono jeden region i jeden subregion o wysokiej przydatności (tab. 2). W ramach zbiornika dolnej kredy jest to subregion gnieźnieńsko-pabianicki (B3). Region poznańsko-kaliski (B) o wysokiej przydatności dotyczy natomiast zbiornika geotermalnego dolnej jury. Przydatnością umiarkowaną w ramach zbiornika dolnej kredy cechują się: region brodnicko-mszczonowski (A), czarnkowsko-wagrowiecki (C) i subregion nowogrodzko-drawieński (D2). Umiarko-

Tab. 1. Wartościowanie regionów i subregionów hydrogeotermalnych z potencjałem ciepłowniczym w zakresie temperatur $>60^{\circ} \mathrm{C}$ Table 1. Valuation of hydrogeothermal regions and subregions potentially useful for space heating with temperatures higher than $60^{\circ} \mathrm{C}$

\begin{tabular}{|c|c|c|c|c|c|c|c|c|c|c|}
\hline $\begin{array}{l}\text { Wiek } \\
\text { Age }\end{array}$ & $\begin{array}{l}\text { Region } \\
\text { Region }\end{array}$ & $\begin{array}{l}\text { Symbol } \\
\text { Symbol }\end{array}$ & $\begin{array}{l}\text { Subregion } \\
\text { Subregion }\end{array}$ & $\begin{array}{l}\text { Symbol } \\
\text { Symbol }\end{array}$ & $\mathbf{T}$ & Min. & Wyd. & $\begin{array}{l}\text { Strumień } \\
\text { cieplny } \\
\text { Heat flow } \\
\text { density }\end{array}$ & $\begin{array}{c}\text { Glębokość } \\
\text { spągu } \\
\text { Depth of } \\
\text { aquifer } \\
\text { bottom }\end{array}$ & $\begin{array}{c}\text { Kategoria } \\
\text { Category }\end{array}$ \\
\hline \multirow{3}{*}{ K1 } & \multirow{2}{*}{$\begin{array}{l}\text { żnińsko-pabianicki } \\
\text { Żnin-Pabianice }\end{array}$} & \multirow[t]{2}{*}{ B } & $\begin{array}{l}\text { goplańsko-uniejowski } \\
\text { Gopło-Uniejów }\end{array}$ & B1 & $10 \%$ & $20 \%$ & $10 \%$ & $5 \%$ & $5 \%$ & B $(50 \%)$ \\
\hline & & & $\begin{array}{l}\text { licheński } \\
\text { Licheń }\end{array}$ & B2 & $10 \%$ & $0 \%$ & $10 \%$ & $5 \%$ & $5 \%$ & $\mathrm{C}(30 \%)$ \\
\hline & $\begin{array}{l}\text { szczecińsko-strzelecki } \\
\text { Szczecin-Strzelce }\end{array}$ & D & $\begin{array}{l}\text { stargardzko-chociwelski } \\
\text { Stargard-Chociwel }\end{array}$ & D1 & $10 \%$ & $0 \%$ & $10 \%$ & $5 \%$ & $5 \%$ & $\mathrm{C}(35 \%)$ \\
\hline \multirow{4}{*}{$\mathrm{J} 1$} & $\begin{array}{l}\text { piotrkowsko-radomski } \\
\text { Piotrków-Radom }\end{array}$ & A & $\begin{array}{l}\text { łódzki } \\
\text { Łódź }\end{array}$ & A1 & $10 \%$ & $20 \%$ & $20 \%$ & $5 \%$ & $5 \%$ & B $(60 \%)$ \\
\hline & $\begin{array}{l}\text { pomorsko-mazowiecki } \\
\text { Pomerania-Mazovia }\end{array}$ & $\mathrm{C}$ & $\begin{array}{l}\text { brodnicko-mszczonowski } \\
\text { Brodnica-Mszczonów }\end{array}$ & $\mathrm{C} 1$ & $10 \%$ & $0 \%$ & $20 \%$ & $0 \%$ & $5 \%$ & $\mathrm{C}(35 \%)$ \\
\hline & $\begin{array}{l}\text { toruńsko-kutnowski } \\
\text { Toruń-Kutno }\end{array}$ & $\mathrm{D}$ & & & $10 \%$ & $10 \%$ & $20 \%$ & $10 \%$ & $5 \%$ & $\mathrm{~B}(55 \%)$ \\
\hline & $\begin{array}{l}\text { szczecińsko-koniński } \\
\text { Szczecin-Konin }\end{array}$ & $\mathrm{E}$ & $\begin{array}{l}\text { nowogardzko-skarszewski } \\
\text { Nowogard-Skarszew }\end{array}$ & E1 & $20 \%$ & $10 \%$ & $20 \%$ & $10 \%$ & $5 \%$ & B $(65 \%)$ \\
\hline $\mathrm{T} 1$ & $\begin{array}{l}\text { sycowski } \\
\text { Syców }\end{array}$ & $\mathrm{C}$ & $\begin{array}{l}\text { kuźnicki } \\
\text { Kuźnice }\end{array}$ & $\mathrm{C} 1$ & $10 \%$ & $10 \%$ & $10 \%$ & $5 \%$ & $0 \%$ & $\mathrm{C}(35 \%)$ \\
\hline
\end{tabular}

Wagi parametrów: T (temperatura wód) $-30 \%\left(>80^{\circ} \mathrm{C}=30 \%, 70-80^{\circ} \mathrm{C}=20 \%, 60-70{ }^{\circ} \mathrm{C}=10 \%\right) ;$ Min. (mineralizacja wód) $-30 \%\left(<16 \mathrm{~g} / \mathrm{dm}{ }^{3}=30 \%\right.$, $16-35 \mathrm{~g} / \mathrm{dm}^{3}=20 \%, 36-70 \mathrm{~g} / \mathrm{dm}^{3}=10 \%,>70 \mathrm{~g} / \mathrm{dm}^{3}=0 \%$ ); Wyd. (prognozowana wydajność) $-20 \%\left(>100 \mathrm{~m}^{3} / \mathrm{h}=20 \%, 30-100 \mathrm{~m}^{3} / \mathrm{h}=10 \%,<30 \mathrm{~m}^{3} / \mathrm{h}=0 \%\right.$ ); Strumień cieplny $-10 \%\left(>90 \mathrm{~mW} / \mathrm{m}^{2}=10 \%, 70-90 \mathrm{~mW} / \mathrm{m}^{2}=5 \%,<70 \mathrm{~mW} / \mathrm{m}^{2}=0 \%\right) ;$ Spag (głębokość zalegania skał wodonośnych) - $10 \%(<1500 \mathrm{~m}=$ $=10 \%, 1500-2500 \mathrm{~m}=5 \%,>2500 \mathrm{~m}=0 \%)$. Kategoria przydatności ciepłowniczej regionu/subregionu geotermalnego: A (suma $>70 \%)-$ przydatność wysoka; B (suma 50-70\%) - przydatność umiarkowana; C (suma 25-49\%) - przydatność niska; D (suma $<25 \%$ ) - nieprzydatny.

Weight of parameters: $\mathrm{T}$ (water temperature) $-30 \%\left(>80^{\circ} \mathrm{C}=30 \%, 70-80{ }^{\circ} \mathrm{C}=20 \%, 60-70^{\circ} \mathrm{C}=10 \%\right)$; Min. (water mineralization) $-30 \%\left(<16 \mathrm{~g} /\right.$ dm ${ }^{3}=$ $=30 \%, 16-35 \mathrm{~g} / \mathrm{dm}^{3}=20 \%, 36-70 \mathrm{~g} / \mathrm{dm}^{3}=10 \%,>70 \mathrm{~g} / \mathrm{dm}^{3}=0 \%$ ); Wyd. (projected efficiency) $-20 \%\left(>100 \mathrm{~m}^{3} / \mathrm{h}=20 \%, 30-100 \mathrm{~m}^{3} / \mathrm{h}=10 \%\right.$, $\left.<30 \mathrm{~m}^{3} / \mathrm{h}=0 \%\right)$; Heat flow density $-10 \%\left(>90 \mathrm{~mW} / \mathrm{m}^{2}=10 \%, 70-90 \mathrm{~mW} / \mathrm{m}^{2}=5 \%,<70 \mathrm{~mW} / \mathrm{m}^{2}=0 \%\right) ;$ Depth of aquifer bottom $-10 \%(<1500 \mathrm{~m}=10 \%$, $1500-2500 \mathrm{~m}=5 \%,>2500 \mathrm{~m}=0 \%$ ). Category of usefulness for heating purposes of particular hydrogeothermal region/subregion: A (sum $>70 \%)$ - high; B (sum 50-70\%) - moderate; C (sum 25-49\%) - low; D (sum $<25 \%)$ - useless. 
Tab. 2. Wartościowanie regionów i subregionów geotermalnych z potencjałem ciepłowniczym w zakresie temperatur $40-60^{\circ} \mathrm{C}$ Table 2. Valuation of hydrogeothermal regions and subregions potentially useful for space heating with temperatures $40-60^{\circ} \mathrm{C}$

\begin{tabular}{|c|c|c|c|c|c|c|c|c|c|c|}
\hline $\begin{array}{l}\text { Wiek } \\
\text { Age }\end{array}$ & $\begin{array}{l}\text { Region } \\
\text { Region }\end{array}$ & $\begin{array}{l}\text { Symbol } \\
\text { Symbol }\end{array}$ & $\begin{array}{l}\text { Subregion } \\
\text { Subregion }\end{array}$ & $\begin{array}{l}\text { Symbol } \\
\text { Symbol }\end{array}$ & $\mathbf{T}$ & Min. & Wyd. & $\begin{array}{c}\text { Strumień } \\
\text { cieplny } \\
\text { Heat flow } \\
\text { density }\end{array}$ & $\begin{array}{c}\text { Glębokość } \\
\text { spągu } \\
\text { Depth of } \\
\text { aquifer } \\
\text { bottom } \\
\end{array}$ & $\begin{array}{c}\text { Kategoria } \\
\text { Category }\end{array}$ \\
\hline \multirow{7}{*}{ K1 } & $\begin{array}{l}\text { brodnicko-mszczonowski } \\
\text { Brodnica-Mszczonów }\end{array}$ & A & & & $20 \%$ & $30 \%$ & $10 \%$ & $0 \%$ & $5 \%$ & B $(65 \%)$ \\
\hline & $\begin{array}{l}\text { żnińsko-pabianicki } \\
\text { Żnin-Pabianice }\end{array}$ & B & & & & & & & & \\
\hline & & & $\begin{array}{l}\text { gnieźnieńsko-pabianicki } \\
\text { Gniezno-Pabianice }\end{array}$ & B3 & $25 \%$ & $20 \%$ & $20 \%$ & $5 \%$ & $5 \%$ & $\mathrm{~A}(75 \%)$ \\
\hline & $\begin{array}{l}\text { czarnkowsko-wagrowiecki } \\
\text { Czarnków-Wagrowiec }\end{array}$ & $\mathrm{C}$ & & & $15 \%$ & $15 \%$ & $10 \%$ & $5 \%$ & $5 \%$ & $\mathrm{~B}(50 \%)$ \\
\hline & $\begin{array}{l}\text { szczecińsko-strzelecki } \\
\text { Szczecin-Strzelce }\end{array}$ & \multirow{2}{*}{ D } & & & & & & & & \\
\hline & & & $\begin{array}{l}\text { nowogrodzko-drawieński } \\
\text { Nowogard-Drawno }\end{array}$ & D2 & $25 \%$ & $15 \%$ & $0 \%$ & $7 \%$ & $5 \%$ & B (52\%) \\
\hline & $\begin{array}{l}\text { józefowski } \\
\text { Józefów }\end{array}$ & E & & & $15 \%$ & $10 \%$ & $0 \%$ & $0 \%$ & $7 \%$ & $\mathrm{C}(32 \%)$ \\
\hline \multirow{8}{*}{$\mathrm{J} 1$} & $\begin{array}{l}\text { piotrkowsko-radomski } \\
\text { Piotrków-Radom }\end{array}$ & \multirow{3}{*}{ A } & & & & & & & & \\
\hline & & & $\begin{array}{l}\text { piotrkowsko-garwoliński } \\
\text { Piotrków-Garwolin }\end{array}$ & A2 & $20 \%$ & $20 \%$ & $15 \%$ & $0 \%$ & $5 \%$ & B $(60 \%)$ \\
\hline & & & $\begin{array}{l}\text { jedliński } \\
\text { Jedlińsk }\end{array}$ & $\mathrm{A} 3$ & $10 \%$ & $30 \%$ & $10 \%$ & $0 \%$ & $5 \%$ & B (55\%) \\
\hline & $\begin{array}{l}\text { poznańsko-kaliski } \\
\text { Poznań-Kalisz }\end{array}$ & B & & & $15 \%$ & $25 \%$ & $20 \%$ & $10 \%$ & $5 \%$ & A $(75 \%)$ \\
\hline & $\begin{array}{l}\text { pomorsko-mazowiecki } \\
\text { Pomerania-Mazovia }\end{array}$ & \multirow{2}{*}{$\mathrm{C}$} & & & & & & & & \\
\hline & & & $\begin{array}{l}\text { chojnicko-warszawski } \\
\text { Chojnice-Warszawa }\end{array}$ & $\mathrm{C} 2$ & $15 \%$ & $10 \%$ & $15 \%$ & $0 \%$ & $3 \%$ & $\mathrm{C}(43 \%)$ \\
\hline & $\begin{array}{l}\text { szczecińsko-koniński } \\
\text { Szczecin-Konin }\end{array}$ & \multirow{2}{*}{ E } & & & & & & & & \\
\hline & & & $\begin{array}{l}\text { pyrzycko-wrześnieński } \\
\text { Pyrzyce-Września }\end{array}$ & E2 & $20 \%$ & $5 \%$ & $20 \%$ & $5 \%$ & $5 \%$ & B (55\%) \\
\hline \multirow{6}{*}{$\mathrm{T} 1$} & $\begin{array}{l}\text { przasnysko-kozienicki } \\
\text { Przasnysz-Kozienice }\end{array}$ & A & & & $15 \%$ & $5 \%$ & $0 \%$ & $5 \%$ & $5 \%$ & $\mathrm{C}(25 \%)$ \\
\hline & $\begin{array}{l}\text { opoczniański } \\
\text { Opoczno }\end{array}$ & B & & & $20 \%$ & $5 \%$ & $5 \%$ & $5 \%$ & $3 \%$ & C (38\%) \\
\hline & $\begin{array}{l}\text { sycowski } \\
\text { Syców }\end{array}$ & \multirow{3}{*}{$\mathrm{C}$} & & & & & & & & \\
\hline & & & $\begin{array}{l}\text { oleśnicki } \\
\text { Oleśnica }\end{array}$ & $\mathrm{C} 2$ & $15 \%$ & $20 \%$ & $5 \%$ & $5 \%$ & $7 \%$ & B (52\%) \\
\hline & & & $\begin{array}{l}\text { bobrownicko-krzepicki } \\
\text { Bobrowniki-Krzepice }\end{array}$ & $\mathrm{C} 3$ & $20 \%$ & $5 \%$ & $5 \%$ & $5 \%$ & $5 \%$ & C (40\%) \\
\hline & $\begin{array}{l}\text { szczuciński } \\
\text { Szczucin }\end{array}$ & D & & & $15 \%$ & $20 \%$ & $0 \%$ & $0 \%$ & $5 \%$ & $\mathrm{C}(40 \%)$ \\
\hline
\end{tabular}

Wagi parametrów: T (temperatura wód) $-30 \%\left(50-60{ }^{\circ} \mathrm{C}=30 \%, 40-49^{\circ} \mathrm{C}=15 \%\right) ;$ Min. (mineralizacja wód) $-30 \%\left(<16 \mathrm{~g} / \mathrm{dm}{ }^{3}=30 \%, 16-35 \mathrm{~g} / \mathrm{dm}{ }^{3}=\right.$ $=20 \%, 36-70 \mathrm{~g} / \mathrm{dm}^{3}=10 \%,>70 \mathrm{~g} / \mathrm{dm}^{3}=0 \%$ ); Wyd. (prognozowana wydajność) $-20 \%\left(>100 \mathrm{~m}^{3} / \mathrm{h}=20 \%, 30-100 \mathrm{~m}^{3} / \mathrm{h}=10 \%,<30 \mathrm{~m} / \mathrm{h}=0 \%\right.$ ); Strumień cieplny $-10 \%\left(>90 \mathrm{~mW} / \mathrm{m}^{2}=10 \%, 70-90 \mathrm{~mW} / \mathrm{m}^{2}=5 \%,<70 \mathrm{~mW} / \mathrm{m}^{2}=0 \%\right)$; Spąg (głębokość zalegania skał wodonośnych) - 10\% $(<1000 \mathrm{~m}=$ $=10 \%, 1000-2000 \mathrm{~m}=5 \%,>2000 \mathrm{~m}=0 \%)$. Kategoria przydatności ciepłowniczej regionu/subregionu geotermalnego: A (suma $>70 \%)-$ przydatność wysoka; B (suma 50-70\%) - przydatność umiarkowana; C (suma 25-49\%) - przydatność niska; D (suma $<25 \%$ ) - nieprzydatny.

Weight of parameters: $T$ (water temperature) $-30 \%\left(50-60^{\circ} \mathrm{C}=30 \%, 40-49^{\circ} \mathrm{C}=15 \%\right) ;$ Min. (water mineralization) $-30 \%\left(<16 \mathrm{~g} /\right.$ dm ${ }^{3}=30 \%$, $\left.16-35 \mathrm{~g} / \mathrm{dm}^{3}=20 \%, 36-70 \mathrm{~g} / \mathrm{dm}^{3}=10 \%,>70 \mathrm{~g} / \mathrm{dm}^{3}=0 \%\right) ;$ Wyd. (projected efficiency) $-20 \%\left(>100 \mathrm{~m}^{3} / \mathrm{h}=20 \%, 30-100 \mathrm{~m}^{3} / \mathrm{h}=10 \%,<30 \mathrm{~m} / \mathrm{h}=0 \%\right)$; Heatflow density $-10 \%\left(>90 \mathrm{~mW} / \mathrm{m}^{2}=10 \%, 70-90 \mathrm{~mW} / \mathrm{m}^{2}=5 \%,<70 \mathrm{~mW} / \mathrm{m}^{2}=0 \%\right) ;$ Depth of aquifer bottom $-10 \%(<1000 \mathrm{~m}=10 \%, 1000-2000 \mathrm{~m}=$ $=5 \%,>2000 \mathrm{~m}=0 \%$ ). Category of usefulness for heating purposes of particular hydrogeothermal region/subregion: A (sum $>70 \%)-$ high; B (sum 50-70\%)-moderate; C (sum 25-49\%) - low; D (sum <25\%)-useless.

waną przydatność mają też regiony i subregiony zbiornika dolnej jury: piotrkowsko-garwoliński (A2), jedliński (A3) i pyrzycko-wrześnieński (E2). W obrębie zbiornika triasu dolnego obszarem o przydatności umiarkowanej jest tylko subregion oleśnicki (C2). Pozostałe, wyróżnione tutaj jednostki tego zbiornika cechuje niska przydatność do celów ciepłownictwa wspomaganego.

W obrębie zbiorników kredy dolnej i jury dolnej wyróżniono subregiony o wysokiej przydatności wód termalnych do celów rekreacji (tab. 3). Są to subregiony: płocko-ra- domski (A1, zbiornik dolnej kredy), uniejowski (B1, zbiornik kredy dolnej) i bełchatowsko-białobrzeski (B1, zbiornik jury dolnej). Pozostałe regiony i subregiony zbiornika hydrogeotermalnego jury dolnej, poza bartoszycko-garwolińskim (A2) o przydatności niskiej, sklasyfikowano jako miejsca o przydatności umiarkowanej. W zbiorniku geotermalnym dolnej kredy niską przydatnością cechują się: subregion chojnicko-warszawski (A2) oraz regiony - gorzowsko-poznański (C) i zamojski (D). Przydatność umiarkowaną ma tutaj tylko subregion czarnkowsko-ra- 
Tab. 3. Wartościowanie regionów i subregionów geotermalnych z potencjałem w zakresie rekreacji

Table 3. Valuation of hydrogeothermal regions and subregions potentially useful for recreation purposes

\begin{tabular}{|c|c|c|c|c|c|c|c|c|c|c|}
\hline $\begin{array}{l}\text { Wiek } \\
\text { Age }\end{array}$ & $\begin{array}{l}\text { Region } \\
\text { Region }\end{array}$ & $\begin{array}{l}\text { Symbol } \\
\text { Symbol }\end{array}$ & $\begin{array}{l}\text { Subregion } \\
\text { Subregion }\end{array}$ & $\begin{array}{l}\text { Symbol } \\
\text { Symbol }\end{array}$ & $\mathbf{T}$ & Min. & Wyd. & $\begin{array}{c}\text { Strumień } \\
\text { cieplny } \\
\text { Heat flow } \\
\text { density }\end{array}$ & $\begin{array}{l}\text { Glębokość } \\
\text { spągu } \\
\text { Depth of } \\
\text { aquifer } \\
\text { bottom }\end{array}$ & $\begin{array}{c}\text { Kategoria } \\
\text { Category }\end{array}$ \\
\hline \multirow{8}{*}{ K1 } & $\begin{array}{l}\text { nadwiślański } \\
\text { Vistula }\end{array}$ & A & & & & & & & & \\
\hline & & & $\begin{array}{l}\text { płocko-radomski } \\
\text { Plock-Radom }\end{array}$ & A1 & $30 \%$ & $30 \%$ & $15 \%$ & $0 \%$ & $5 \%$ & $\mathrm{~A}(80 \%)$ \\
\hline & & & $\begin{array}{l}\text { chojnicko-warszawski } \\
\text { Chojnice-Warszawa }\end{array}$ & $\mathrm{A} 2$ & $10 \%$ & $10 \%$ & $5 \%$ & $0 \%$ & $8 \%$ & C (33\%) \\
\hline & $\begin{array}{l}\text { gnieźniańsko-piotrkowski } \\
\text { Gniezno-Piotrków }\end{array}$ & B & & & & & & & & \\
\hline & & & $\begin{array}{l}\text { uniejowski } \\
\text { Uniejów }\end{array}$ & B1 & $30 \%$ & $15 \%$ & $20 \%$ & $5 \%$ & $5 \%$ & A $(75 \%)$ \\
\hline & & & $\begin{array}{l}\text { czarnkowsko- } \\
\text {-radomszczański } \\
\text { Czarnków-Radomsko }\end{array}$ & B2 & $15 \%$ & $10 \%$ & $15 \%$ & $5 \%$ & $10 \%$ & B (55\%) \\
\hline & $\begin{array}{l}\text { gorzowsko-poznański } \\
\text { Gorzów-Poznań }\end{array}$ & $\mathrm{C}$ & & & $5 \%$ & $15 \%$ & $5 \%$ & $10 \%$ & $10 \%$ & $\mathrm{C}(45 \%)$ \\
\hline & $\begin{array}{l}\text { zamojski } \\
\text { Zamość }\end{array}$ & D & & & $7 \%$ & $5 \%$ & $5 \%$ & $0 \%$ & $10 \%$ & C (27\%) \\
\hline \multirow{13}{*}{$\mathrm{J} 1$} & $\begin{array}{l}\text { warmińsko-mazowiecki } \\
\text { Warmia-Mazovia }\end{array}$ & A & & & & & & & & \\
\hline & & & $\begin{array}{l}\text { wielbarsko-maciejowicki } \\
\text { Wielbark-Maciejowice }\end{array}$ & A1 & $30 \%$ & $5 \%$ & $20 \%$ & $0 \%$ & $5 \%$ & B $(60 \%)$ \\
\hline & & & $\begin{array}{l}\text { bartoszycko-garwoliński } \\
\text { Bartoszyce-Garwolin }\end{array}$ & A2 & $10 \%$ & $15 \%$ & $10 \%$ & $0 \%$ & $10 \%$ & C (45\%) \\
\hline & $\begin{array}{l}\text { pabianicko-radomski } \\
\text { Pabianice-Radom }\end{array}$ & B & & & & & & & & \\
\hline & & & $\begin{array}{l}\text { bełchatowsko-białobrzeski } \\
\text { Betchatów-Białobrzegi }\end{array}$ & B1 & $30 \%$ & $12 \%$ & $20 \%$ & $5 \%$ & $5 \%$ & A $(72 \%)$ \\
\hline & & & $\begin{array}{l}\text { łódzko-iłżański } \\
\text { Łódź-Ilża }\end{array}$ & B2 & $15 \%$ & $25 \%$ & $20 \%$ & $3 \%$ & $5 \%$ & B (68\%) \\
\hline & $\begin{array}{l}\text { nadwarciański } \\
\text { Warta }\end{array}$ & $\mathrm{C}$ & & & & & & & & \\
\hline & & & $\begin{array}{l}\text { świebodzińsko- } \\
\text {-radomszczański } \\
\text { Świebodzin-Radomsko }\end{array}$ & $\mathrm{C} 1$ & $30 \%$ & $5 \%$ & $20 \%$ & $7 \%$ & $5 \%$ & B (67\%) \\
\hline & & & $\begin{array}{l}\text { swarzędzko-pyzdrzański } \\
\text { Swarzędz-Pyzdry }\end{array}$ & $\mathrm{C} 2$ & $15 \%$ & $15 \%$ & $20 \%$ & $8 \%$ & $10 \%$ & B (68\%) \\
\hline & $\begin{array}{l}\text { zachodniopomorski } \\
\text { West Pomeranian }\end{array}$ & D & & & & & & & & \\
\hline & & & $\begin{array}{l}\text { kołobrzesko-złotowski } \\
\text { Kołobrzeg-Ztotów }\end{array}$ & D1 & $8 \%$ & $20 \%$ & $20 \%$ & $5 \%$ & $8 \%$ & B (61\%) \\
\hline & & & $\begin{array}{l}\text { stobnieński } \\
\text { Stobno }\end{array}$ & D2 & $30 \%$ & $5 \%$ & $20 \%$ & $5 \%$ & $8 \%$ & B (68\%) \\
\hline & $\begin{array}{l}\text { łęczycki } \\
\text { Łęczyca }\end{array}$ & E & & & $30 \%$ & $5 \%$ & $20 \%$ & $5 \%$ & $3 \%$ & B (63\%) \\
\hline \multirow{7}{*}{$\mathrm{T} 1$} & $\begin{array}{l}\text { podlaski } \\
\text { Podlasie }\end{array}$ & A & & & & & & & & \\
\hline & & & $\begin{array}{l}\text { tykocińsko-międzyrzecki } \\
\text { Tykocin-Miedzyrzec }\end{array}$ & A1 & $15 \%$ & $10 \%$ & $7 \%$ & $0 \%$ & $5 \%$ & C (37\%) \\
\hline & & & $\begin{array}{l}\text { łosicki } \\
\text { Eosice }\end{array}$ & A2 & $5 \%$ & $30 \%$ & $5 \%$ & $0 \%$ & $5 \%$ & C (45\%) \\
\hline & $\begin{array}{l}\text { szczuciński } \\
\text { Szczucin }\end{array}$ & B & & & $30 \%$ & $20 \%$ & $5 \%$ & $0 \%$ & $5 \%$ & B $(60 \%)$ \\
\hline & $\begin{array}{l}\text { mniowski } \\
\text { Mniów }\end{array}$ & $\mathrm{C}$ & & & $15 \%$ & $5 \%$ & $8 \%$ & $5 \%$ & $5 \%$ & C (38\%) \\
\hline & $\begin{array}{l}\text { lubińsko-częstochowski } \\
\text { Lubin-Częstochowa }\end{array}$ & D & & & $13 \%$ & $12 \%$ & $10 \%$ & $6 \%$ & $7 \%$ & C (48\%) \\
\hline & $\begin{array}{l}\text { słupski } \\
\text { Stupsk }\end{array}$ & $\mathrm{E}$ & & & $5 \%$ & $5 \%$ & $5 \%$ & $4 \%$ & $10 \%$ & C (29\%) \\
\hline
\end{tabular}

Wagi parametrów: T (temperatura wód) $-30 \%\left(40-50^{\circ} \mathrm{C}=30 \%, 30-39^{\circ} \mathrm{C}=20 \%, 20-29^{\circ} \mathrm{C}=5 \%\right)$; Min. (mineralizacja wód) $-30 \%\left(<5 \mathrm{~g} / \mathrm{dm}^{3}=30 \%\right.$, $5-20 \mathrm{~g} / \mathrm{dm}^{3}=20 \%, 21-35 \mathrm{~g} / \mathrm{dm}^{3}=5 \%$ ); Wyd. (prognozowana wydajność) $-20 \%\left(>30 \mathrm{~m}^{3} / \mathrm{h}=20 \%, 15-30 \mathrm{~m}^{3} / \mathrm{h}=10 \%, 5-14 \mathrm{~m}^{3} / \mathrm{h}=5 \%\right) ;$ Strumień cieplny $-10 \%\left(>90 \mathrm{~mW} / \mathrm{m}^{2}=10 \%, 70-90 \mathrm{~mW} / \mathrm{m}^{2}=5 \%,<70 \mathrm{~mW} / \mathrm{m}^{2}=0 \%\right) ;$ Spag (głębokość zalegania skał wodonośnych) $-10 \%(<1000 \mathrm{~m}=10 \%$, 1000-2000 $\mathrm{m}=5 \%,>2000 \mathrm{~m}=0 \%$ ). Kategoria przydatności dla celów rekreacji regionu/subregionu geotermalnego: A (suma $>70 \%)-$ przydatność wysoka; B (suma 50-70\%) - przydatność umiarkowana; C (suma 25-49\%) - przydatność niska; D (suma <25\%) - nieprzydatny.

Weight of parameters: $T$ (water temperature) $-30 \%\left(\geq 40^{\circ} \mathrm{C}=30 \%, 30-39^{\circ} \mathrm{C}=20 \%, 20-29{ }^{\circ} \mathrm{C}=5 \%\right) ;$ Min. $\left(\right.$ water mineralization) $-30 \%\left(<5 \mathrm{~g} / \mathrm{dm}^{3}=30 \%\right.$, $\left.5-20 \mathrm{~g} / \mathrm{dm}^{3}=20 \%, 21-35 \mathrm{~g} / \mathrm{dm}^{3}=5 \%\right) \cdot$ Wyd (projected efficiency) $-20 \%\left(>30 \mathrm{~m}^{3} / \mathrm{h}=20 \%, 15-30 \mathrm{~m}^{3} / \mathrm{h}=10 \%, 5-14 \mathrm{~m}^{3} / \mathrm{h}=5 \%\right)$ : Heat flow density $-10 \%\left(>90 \mathrm{~mW} / \mathrm{m}^{2}=10 \%, 70-90 \mathrm{~mW} / \mathrm{m}^{2}=5 \%,<70 \mathrm{~mW} / \mathrm{m}^{2}=0 \%\right)$; Depth of aquifer bottom $-10 \%(<1000 \mathrm{~m}=10 \%, 1000-2000 \mathrm{~m}=5 \%,>2000 \mathrm{~m}=0 \%)$. Category of usefulness for recreation purposes of particular hydrogeothermal region/subregion: A (sum > 70\%) - high; B (sum 50-70\%) - moderate; C (sum 25-49\%) - low; D (sum <25\%) - useless. 
domszczański (B2). W zbiorniku triasu dolnego prawie wszystkie wyróżnione jednostki to obszary o niskiej przydatności wód termalnych do celów rekreacji. Tylko region szczuciński (B) oceniono jako obszar o umiarkowanej przydatności do tych celów.

\section{PODSUMOWANIE}

Głównym celem tego opracowania była próba regionalizacji użytkowej basenów hydrogeotermalnych kredy dolnej, jury dolnej i triasu dolnego Niżu Polskiego, przeprowadzona na osnowie uproszczonych tutaj, istotnych parametrów tych basenów, zestawionych w wersji szczegółowej w opracowaniu Góreckiego (2006). Właściwości użytkowe poszczególnych rozpatrywanych basenów hydrogeotermalnych są bardzo zróżnicowane. Znaczne ich obszary nie spełniają założonych kryteriów progowych. Basen dolnego triasu, rozpatrywany zarówno w kontekście potrzeb rekreacji jak i też ciepłownictwa, ma znaczenie marginalne. Przeprowadzona walidacja wskazuje, że większość wyróżnionych w jego obrębie regionów charakteryzuje niski potencjał dotyczący obu analizowanych kierunków możliwego wykorzystania wód geotermalnych. Bez wattpienia potencjał geotermalny zbiorników dolnego triasu i dolnej jury obniża fakt powszechnego stowarzyszenia korzystnego wzrostu temperatur wód geotermalnych z niekorzystnym wzrostem ich mineralizacji.

Wody termalne o temperaturach przekraczających $60^{\circ} \mathrm{C}$ i mineralizacji poniżej $100 \mathrm{~g} / \mathrm{dm}^{3}$, czyli potencjalnie użyteczne do niewspomaganego ciepłownictwa, znajdują się głównie w zbiorniku dolnej jury, gdzie wyróżniono jeden region (toruńsko-kutnowski) i dwa subregiony (łódzki i nowogardzko-skarszewski) o umiarkowanej przydatności. W zbiorniku kredy dolnej tylko subregion goplańsko-uniejowski można uznać za umiarkowanie przydatny do tego rodzaju ciepłownictwa.

W zakresie wód termalnych potencjalnie użytecznych dla ciepłownictwa wspomaganego (temperatura $40-60^{\circ} \mathrm{C}$, mineralizacja poniżej $100 \mathrm{~g} / \mathrm{dm}^{3}$ ) dobre warunki przypisano dwóm jednostkom regionalnym. W zbiorniku dolnej kredy jest to subregion gnieźnieńsko-pabianicki, natomiast w zbiorniku jury dolnej - region poznańsko-kaliski. Jako umiarkowanie przydatne w tym zakresie określono osiem jednostek. W zbiorniku dolnej kredy są to regiony brodnicko-mszczonowski i czarnkowsko-wągrowiecki, a także subregion nowogrodzko-drawieński. W zbiorniku jury dolnej są to subregiony: piotrkowsko-garwoliński, jedliński i pyrzycko-wrześnieński. Jako umiarkowanie przydatny określono również subregion oleśnicki zbiornika triasu dolnego.

Trzy jednostki określono jako te o wysokiej przydatności w zakresie rekreacji. W zbiorniku kredy dolnej są to subregiony płocko-radomski i uniejowski. W zbiorniku jury dolnej jest to tylko subregion bełchatowsko-białobrzeski. Należy jednak podkreślić, że w zbiorniku tym wyróżniono aż siedem regionów i subregionów o umiarkowanej przydatności w tym zakresie.

Ze względu na ograniczenia wskazane na początku tego artykułu, przeprowadzony podział na regiony trzech najważniejszych zbiorników hydrogeotermalnych Niżu Polskiego należy traktować jako wstępny. Granice regionów i ich wartościowanie mogą w przyszłości również ulec zmianie nie tylko z powodu napływu nowych danych, lecz również, gdy dalsze doświadczenia z eksploatacji wód termalnych i postęp technologii doprowadzą do zmniejszenia wagi kryterium związanego ze stopniem mineralizacji wód, a zwłaszcza do przeniesienia progu dopuszczalnych jego wartości wyraźnie powyżej $100 \mathrm{~g} / \mathrm{dm}^{3}$, bez większego wpływu na rentowność przedsięwzięć.

Pracę wykonano w ramach zadania państwowej służby geologicznej nr 22.8205.1701.00.1, sfinansowanego ze środków Narodowego Funduszu Ochrony Środowiska i Gospodarki Wodnej. Autorzy dziękuja prof. K.M. Labusowi oraz anonimowemu Recenzentowi za wnikliwe uwagi, które bezsprzecznie przyczyniły się do niezbędnej korekty pierwotnej wersji artykułu.

\section{LITERATURA}

BIELEC B., BUJAKOWSKI W., HOŁOJUCH G., KASZTELEWICZ A., TOMASZEWSKA B., CHOWANIEC J., CZERWIŃSKA B., FARNUS W., FREIWALD P., LEŚNIAK G., OPERACZ T., PRZELASKOWSKA A. 2014 - Ocena uwarunkowań geologiczno-złożowych występowania struktur hydrogeotermalnych. Atlas wykorzystania wód termalnych do skojarzonej produkcji energii elektrycznej i cieplnej w układach binarnych w Polsce. Wyd. ,Jak”, Kraków.

BIERNAT H., KULIK S., NOGA B., KOSMA Z. 2011 - Próba zapobiegania kolmatacji geotermalnych otworów zatłaczających w wyniku zastosowania super miękkiego kwasowania. Modelowanie Inżynierskie, 42: 59-66.

BUJAKOWSKI W., BARBACKI A. 2016 - Triasowy zbiornik wód termalnych w północnej strefie Tarnowa - parametry hydrogeotermalne i perspektywy wykorzystania. Zesz. Nauk. IGSMiE PAN, 82: 325-336. DADLEZ R. (red.) 1998 - Mapa tektoniczna kompleksu cechsztyńsko-mezozoicznego na Niżu Polskim w skali 1 : 500 000. Państw. Inst. Geol., Warszawa.

FELTER A., SKRZYPCZYK L., SOCHA M., SOKOŁOWSKI J., STOŻEK J., GRYCZKO-GOSTYNSSKA A. 2017 - Mapa zagospodarowania wód podziemnych zaliczonych do kopalin w Polsce, skala 1 : 1000000. Państw. Inst. Geol., Warszawa.

GÓRECKI W. (red.) 2006 - Atlas zasobów geotermalnych na Niżu Polskim - formacje mezozoiku - Ministerstwo Srodowiska. AGH, Kraków. HAJTO M. 2008 - Zasoby energii geotermalnej w formacjach mezozoicznych i paleozoicznych Niżu Polskiego. Tech. Posz. Geol., 45 (2): 57-61.

NAWROCKI J. 2021 - Pole geotermiczne i regiony geotermalne na Niżu Polskim. [W:] Socha M. (red.), Ocena potencjału energetycznego i surowcowego wód termalnych i leczniczych termalnych w wybranych obszarach zurbanizowanych wraz z analizą geośrodowiskowych oraz ekonomicznych uwarunkowań ich zagospodarowania (umowa z NFOŚiGW nr 181/2018/Wn-07/FG-sm-dn/D z dnia 10.08.2018). Załącznik nr 3: 1-70. Nar. Arch. Geol. Państw. Inst. Geol., Warszawa.

NEY R., SOKOŁOWSKI J. 1987 - Wody geotermalne Polski i możliwości ich wykorzystania. Nauka Polska, 6: 67-92.

PAJACK L., BUJAKOWSKI W. 2018 - Zmiany ceny zakupu energii cieplnej pochodzącej z polskich ciepłowni geotermalnych w latach 2007-2018 w świetle obowiązujących taryf rozliczeniowych . Tech. Posz. Geol., Geotermia, ZrównoważonyRozwój, 1: 29-35.

RAJCHEL L. 2006 - Zastosowanie wód geotermalnych w balneoterapii i rekreacji. [W:] Górecki W. (red.), Atlas zasobów geotermalnych na Niżu Polskim - formacje mezozoiku - Ministerstwo Srodowiska. AGH, Kraków.

SOKOŁOWSKI J. (red.) 1995 - Prowincje i baseny geotermalne Polski. Wyd. Roma-Pol., Kraków: 121.

SOWIŻDŻAŁ A., HAJTO M., HAŁAJ E. 2020 - Thermal waters of central Poland: a case study from Mogilno - Łódź Trough, Poland. Env. Earth Sci., 79 (5): 1-11.

SZEWCZYK J., GIENTKA D. 2009 - Terrestrial heat flow density in Poland - a new approach. Geol. Quart., 53 (1): 125-140.

Praca wpłynęła do redakcji $9.06 .2021 \mathrm{r}$.

Akceptowano do druku 16.08.2021 r. 